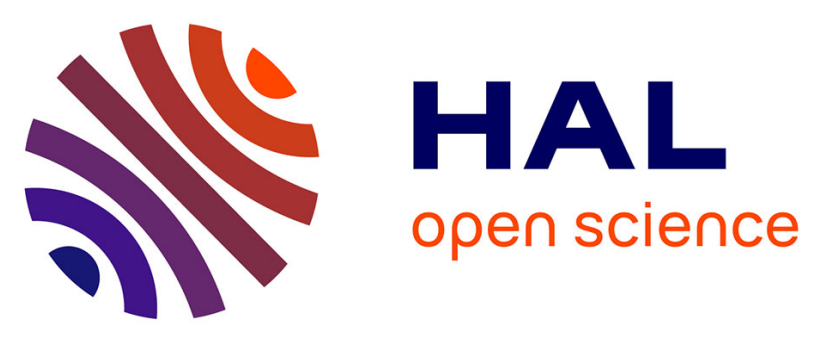

\title{
Prokaryotic diversity and activity in contrasting productivity regimes in late summer in the Kerguelen region (Southern Ocean)
}

\author{
Alejandra Elisa Hernandez-Magana, Yan Liu, Pavla Debeljak, Olivier Crispi, \\ Barbara Marie, Coco Koedooder, Ingrid Obernosterer
}

\section{To cite this version:}

Alejandra Elisa Hernandez-Magana, Yan Liu, Pavla Debeljak, Olivier Crispi, Barbara Marie, et al.. Prokaryotic diversity and activity in contrasting productivity regimes in late summer in the Kerguelen region (Southern Ocean). Journal of Marine Systems, 2021, 221, pp.103561. 10.1016/j.jmarsys.2021.103561 . hal-03435534

\author{
HAL Id: hal-03435534 \\ https://hal.science/hal-03435534
}

Submitted on 18 Nov 2021

HAL is a multi-disciplinary open access archive for the deposit and dissemination of scientific research documents, whether they are published or not. The documents may come from teaching and research institutions in France or abroad, or from public or private research centers.
L'archive ouverte pluridisciplinaire HAL, est destinée au dépôt et à la diffusion de documents scientifiques de niveau recherche, publiés ou non, émanant des établissements d'enseignement et de recherche français ou étrangers, des laboratoires publics ou privés. 
Prokaryotic diversity and activity in contrasting productivity regimes in late summer in the Kerguelen region (Southern Ocean)

Alejandra Elisa Hernandez-Magana ${ }^{1,2 *}$, Yan Liu ${ }^{1,3 *}$, Pavla Debeljak ${ }^{1,4 \dagger}$, Olivier Crispi ${ }^{1}$, 5 Barbara Marie ${ }^{1}$, Coco Koedooder ${ }^{1}+$ Ingrid Obernosterer $^{1 \#}$

${ }^{1}$ Sorbonne Université, CNRS, Laboratoire d'Océanographie Microbienne, LOMIC, F-66650, Banyuls/mer, France.

${ }^{2}$ Nordcee, Department of Biology, University of Southern Denmark, Odense M, Denmark

${ }^{3}$ School of Life Sciences, Ludong University, Yantai, China

${ }^{4}$ University of Vienna, Department of Functional and Evolutionary Ecology, A-1090 Vienna, Austria

present affiliation

${ }^{\dagger}$ Institut de Systématique, Évolution, Biodiversité (ISYEB), Muséum National d'Histoire

15 Naturelle, CNRS, Sorbonne Université

$\$$ The Fredy and Nadine Herrmann Institute of Earth Sciences, Hebrew University of Jerusalem, Jerusalem, Israel

*These authors contributed equally to this study.

\# Corresponding author: Ingrid Obernosterer, Microbial Oceanography Laboratory (LOMIC), CNRS-Sorbonne University, 1 Avenue Pierre Fabre, 66650 Banyuls sur mer, France.

Tel: (+33) 0468887353

e-mail: ingrid.obernosterer@obs-banyuls.fr

Keywords: prokaryotic community composition, $16 \mathrm{~S}$ rRNA, amplicon sequence variants, natural iron fertilization, Southern Ocean 
Natural iron $(\mathrm{Fe})$ fertilization sustains phytoplankton blooms above the Kerguelen plateau (Indian sector of the Southern Ocean) within otherwise low productive off-plateau waters. In early spring and summer, these diatom-dominated blooms are associated with distinct heterotrophic prokaryotic communities, but whether a structuring effect extends to the postbloom period has thus far not been investigated. To address this question, we carried out a detailed study of the prokaryotic community composition in the region of Kerguelen Island during late Austral summer (18 February to 27 March 2018; MOBYDICK project). Concentrations of chlorophyll $a$ were seasonally low above the plateau $\left(0.27-0.58 \mu \mathrm{g} \mathrm{Chl} a \mathrm{~L}^{-}\right.$ $\left.{ }^{1}\right)$ and in a similar range to those at the 3 off-plateau sites investigated (0.14-0.34 $\mu \mathrm{g} \mathrm{Chl} a \mathrm{~L}^{-}$ ${ }^{1}$ ), but we observed an accumulation of dissolved organic carbon and the build-up of heterotrophic prokaryotic biomass in Kerguelen plateau waters. Illumina sequencing of the 16S rRNA gene revealed that the total (DNA-based) and potentially active (RNA-based) prokaryotic communities were structured according to on- and off-plateau sites in the windmixed surface layer, in both the free-living $(<0.8 \mu \mathrm{m}$ size fraction) and particle-attached $(>$ $0.8 \mu \mathrm{m}$ size fraction) size fractions. The Amplicon Sequence Variants (ASV) with significantly higher relative abundances in on-plateau surface waters as compared to offplateau waters belonged to Halieaceae OM60 group, several Flavobacteriaceae, such as the NS5 marine group, Aurantivirga and Ulvibacter, Rhodobacteraceae Loktanella, Saprospiraceae, and the Cryomorphaceae NS10 marine group. ASVs with higher relative abundances in off-plateau waters belonged to the Flavobacteriaceae Formosa, the Rhodobacteraceae Planktomarina and the SAR1 1 clade. We discuss the potential abiotic and biotic drivers of community composition in late Austral summer and the ecological roles of abundant prokaryotic taxa in Kerguelen plateau waters. 
Heterotrophic prokaryotes contribute to the cycling of all elements in the ocean. Within the marine carbon cycle, they process roughly half of recent primary production with most of the organic carbon being respired (Ducklow et al., 2007). This process mediates large fluxes of carbon and energy between autotrophic and heterotrophic microbial communities and has important consequences for the potential storage of carbon in the ocean interior by the biological pump. Phytoplankton blooms are seasonally re-occurring events that stimulate prokaryotic and higher trophic level growth and metabolic activity. Diverse prokaryotes carry out the transformation of phytoplankton-derived organic matter (reviewed in Buchan et al., (2014)) and the response is generally most pronounced a few weeks after the peak in phytoplankton biomass (Bunse and Pinhassi, 2017). The observed succession in prokaryotic communities over the course of phytoplankton blooms (Teeling et al., 2012) illustrates the dynamic interplay between the composition of organic matter released by phototrophs, the metabolic capabilities of individual taxa, and the potential species-specific phytoplanktonprokaryote associations. opportunities to investigate these processes in the otherwise low-productive Southern Ocean. The region east of Kerguelen Island harbors the largest phytoplankton blooms induced by natural Fe fertilization (Blain et al., 2007). Prokaryotes contribute substantially to the transformation of phytoplankton-derived organic matter during early spring (November), summer (January-February) and late summer (February-March) corresponding to the onset, peak and early decline, and the post-bloom phases in these perennially cold waters (Christaki et al., 2020). These diatom-dominated blooms (Armand et al., 2008; Lasbleiz et al., 2016; Blain et al., 2020) are associated with prokaryotic heterotrophic communities during early spring (Landa et al., 2016) and in summer (West et al., 2008; Obernosterer et al., 2011) that 
are distinct to those in surrounding low-productive waters. Onboard experiments have highlighted the role of diatom-derived organic matter in shaping prokaryotic community composition in spring (Landa et al., 2016), and potential associations between diatom species and prokaryotic taxa has been identified as mechanism for the temporal structuring of microbial communities (Liu et al., 2020). Observations from the post-bloom period when phytoplankton biomass has similar levels in on and off-plateau waters are thus far lacking, preventing to address the question on the effects Fe-fertilization on prokaryotic community composition at the seasonal scale in the Southern Ocean.

Numerous studies have described prokaryotic communities in different size-fractions, considered as free-living and particle-attached prokaryotes. The diversity and specific metabolic activity was shown to be higher in communities attached to particles as compared to free-living ones (Ghiglione et al., 2007, Zhang et al., 2007; Ortega-Retuerta et al., 2013; Rieck et al., 2015; Zhang et al., 2020) or unchanged between size-fractions (Bachmann et al., 2018). Observed differences have been associated to the respective lifestyle and metabolic capabilities. The composition, origin and quality of the particles was shown to have a strong influence on the associated prokaryotes (Zhang et al., 2007; Ortega-Retuerta et al., 2013; Rieck et al., 2015). Therefore, exploring the free-living and particle-attached community structure can provide a better understanding of the processes influencing the prokaryotic diversity.

The present study was carried out as part of the project MOBYDICK (Marine Ecosystem Biodiversity and Dynamics of Carbon around Kerguelen: an integrated view) that aimed to provide a detailed picture of the diversity and role in the carbon cycling of biological communities of end-to-end food webs in contrasting nutrient regimes in the Southern Ocean. Our specific objective was to provide a description of the prokaryotic community composition. We considered the total (DNA-based) and potentially active (RNA-based) free- 
100 living $(<0.8 \mu \mathrm{m})$ and particle-attached $(>0.8 \mu \mathrm{m})$ prokaryotic communities in the upper $300 \mathrm{~m}$ water column. Our observations from late Austral summer, corresponding to roughly 2 months after the peak of the phytoplankton bloom, reveal distinct prokaryotic communities in Kerguelen plateau surface waters as compared to off-plateau waters. We further identified the prokaryotic taxa that explained the differences between on- and off- plateau waters, providing

105 insights to microbial processes occurring during post-bloom conditions in this fertilized region of the Southern Ocean.

\section{Material \& Methods}

\subsection{Study area}

110 Samples were collected in the region of Kerguelen Island in the Indian Sector of the Southern Ocean in late Austral summer (MOBYDICK cruise; February 18 to March 27, 2018) (Fig. 1). Four stations, identified as MOBYDICK-1 (M1), M2, M3 and M4 were sampled (Table 1). Station M2 is located on the central Kerguelen plateau (overall depth $527 \mathrm{~m}$ ), southeast of Kerguelen Island, in naturally Fe-fertilized waters (Blain et al., 2007). The other three stations

115 are located in off-plateau waters, east (M1) and southwest of Kerguelen Island (M3 and M4). Station M3 is located in the polar frontal zone and stations M1, M2 and M4 are in Antarctic waters, with station M1 being strongly influenced by the polar front (Pauthenet et al., 2018). The sampling period during the MOBYDICK cruise corresponded to roughly two months after the seasonal maximum in chlorophyll $a(\mathrm{Chl} a)$ concentrations in on- and off-plateau waters (Fig. S1). Station M2 was sampled three times (M2-1, M2-2 and M2-3) in an eight-day interval, stations M3 (M3-1 and M3-3) and M4 (M4-1 and M4-2) were each sampled twice with a 14-day interval and station M1 was visited once (Table 1). 


\subsection{Sample collection}

125 Seawater samples were collected with 12 L Niskin bottles mounted on a rosette equipped with a conductivity, temperature, depth sensor (Seabird SBE-911 plus CTD unit). Discrete samples for concentrations of Chl $a$ and dissolved organic carbon (DOC), and prokaryotic abundances were taken at 10 to 12 depths in the upper 500m. The sampling depths for prokaryotic community composition were chosen according to the CTD profiles with the aim to collect seawater at the top and at the base of the surface mixed layer $\left(Z_{M L}\right)$, in the transition layer, and in deeper waters (Fig. S2). We used this strategy to obtain 2 samples from the $\mathrm{Z}_{\mathrm{ML}}$, focus of our study, and to allow for a comparison of the surface water communities with those from deeper layers. Seawater samples were collected at 10m, 60m, 125m and 300m at all sites and visits, except for M2-1, where the following depths were sampled 10m, 50m, 100m and

$135300 \mathrm{~m}$. For clarity, the $50 \mathrm{~m}$ and $100 \mathrm{~m}$ sampling depths at station M2-1 will be referred to 60 $\mathrm{m}$ and $125 \mathrm{~m}$, respectively, in the description of the results and figures. The samples collected at the two uppermost depths were within the $\mathrm{Z}_{\mathrm{ML}}$ at all sites and visits, except for Station M1 where only the uppermost depth was within the shallow $\mathrm{Z}_{\mathrm{ML}}$ (Table 1).

\subsection{Concentration of Chl $a$}

140 For the analysis of $\mathrm{Chl} a$ concentrations, 2.32 $\mathrm{L}$ of seawater were filtered through Whatman GF/F filters and the filters were stored in liquid nitrogen until analysis in the laboratory. Filters were extracted in $100 \%$ methanol, disrupted by sonication and clarified by GF/F filtration after $2 \mathrm{~h}$. Samples were analysed within $24 \mathrm{~h}$ using High Performance Liquid Chromatography on an Agilent Technologies HPLC 1200 system equipped with a diode array detector following (Ras et al., 2008). 


\subsection{Dissolved organic carbon}

The concentration of dissolved organic carbon (DOC) was determined in samples filtered through two combusted $\left(450^{\circ} \mathrm{C}, 4 \mathrm{~h}\right) \mathrm{GF} / \mathrm{F}$ filters. Subsamples of $10 \mathrm{~mL}$ (in triplicate) were transferred to pre-combusted glass ampoules and acidified with $\mathrm{H}_{3} \mathrm{PO}_{4}($ final $\mathrm{pH}=2)$. The sealed glass ampoules were stored in the dark at room temperature until analysis. DOC measurements were performed on a Shimadzu TOC-V-CSH (Benner and Strom, 1993). Prior to injection, DOC samples were sparged with $\mathrm{CO}_{2}$-free air for 6 min to remove inorganic carbon. Hundred $\mu \mathrm{L}$ of each of the sample replicates were injected in triplicate and the analytical precision was $2 \%$. Standards were prepared with acetanilide. Consensus reference materials provided in sealed glass ampoules (http://www.rsmas.miami.edu/groups/biogeochem/CRM.html) was injected every 12 to 17 samples to insure stable operating conditions.

\subsection{Enumeration of heterotrophic prokaryotes}

For the enumeration of heterotrophic prokaryotes by flow cytometry, subsamples $(1.44 \mathrm{~mL})$ were fixed with glutaraldehyde grade I 25\% (1\% final concentration), and incubated for 30 min at $4{ }^{\circ} \mathrm{C}$, then quick-frozen in liquid nitrogen and stored at $-80{ }^{\circ} \mathrm{C}$ until analysis. Samples were collected from unfiltered seawater, considered as the bulk prokaryotic abundance, and

165 from the $<0.8 \mu \mathrm{m}$ size fraction, considered as the abundance of free-living prokaryotes. Samples were thawed at room temperature. Counts were performed on a FACSCanto II flow cytometer (Becton Dickinson) equipped with 3 air-cooled lasers: blue (argon $488 \mathrm{~nm}$ ), red $(633 \mathrm{~nm})$ and violet $(407 \mathrm{~nm})$. For the enumeration of non-autofluorescent cells, mainly heterotrophic prokaryotes, cells were stained with SYBR Green I (Invitrogen - Molecular Probes) at $0.025 \%$ ( vol / vol) final concentration for $15 \mathrm{~min}$ at room temperature in the dark. Stained prokaryotic cells were discriminated and enumerated according to their right-angle 
light scatter (SSC) and green fluorescence at 530/30 nm. In a plot of green versus red fluorescence, non-autofluorescent cells were distinguished from autofluorescent cells. Fluorescent beads (1.002 $\mu \mathrm{m}$; Polysciences Europe) were systematically added to each analyzed sample as internal standard. The cell abundance was determined from the flow rate, which was calculated with TruCount beads (BD biosciences).

\subsection{Prokaryotic community composition}

For the analysis of prokaryotic community composition, seawater was passed through a 60 $\mu \mathrm{m}$ nylon mesh and $6 \mathrm{~L}$ of seawater was filtered through $0.8 \mu \mathrm{m}$ pore-size polycarbonate (PC) membranes (47 mm diameter, Nuclepore, Whatman, Sigma Aldrich, St Louis, MO) to retrieve the particle-attached $(>0.8 \mu \mathrm{m})$ fraction. Prokaryotic cells in the $<0.8 \mu \mathrm{m}$ fraction were concentrated on $0.22 \mu \mathrm{m}$ cartridges (Sterivex ${ }^{\mathrm{TM}}$ Millipore, EMD, Billerica, MA) and considered as free-living fraction. The filters were stored in sterile Eppendorf tubes $(2 \mathrm{ml})$ and the cartridges were sealed at both ends using parafilm. The filters and cartridges were stored at $-80^{\circ} \mathrm{C}$ until DNA and RNA extraction.

DNA and RNA extractions were performed simultaneously from the PC membranes $(>0.8$ $\mu \mathrm{m}$ fraction) and the Sterivex ${ }^{\mathrm{TM}}$ cartridges ( $>0.2 \mu \mathrm{m}$ fraction) respectively, using the AllPrep Kit (Qiagen, Hilden, Germany) as described in (Liu et al., 2019) with minor modifications.

190 The filter units were thawed and closed with a sterile pipette tip end at the outflow, $425 \mu 1$ lysis buffer were added per sample (40mM EDTA, 50mM Tris and $0.75 \mathrm{M}$ sucrose) and three freeze-thaw cycles were performed with liquid nitrogen and a water bath at $65^{\circ} \mathrm{C}$. Subsequently, $25 \mu 1$ of freshly prepared lysozyme solution were added $\left(2 \mathrm{mg} \mathrm{ml}^{-1}\right.$ final concentration), the filter units were placed in a rotary mixer and incubated at $37^{\circ} \mathrm{C}$ during 45

195 minutes, and then $8 \mu \mathrm{l}$ of proteinase $\mathrm{K}$ solution $\left(0.2 \mathrm{mg} \mathrm{ml}^{-1}\right.$ final concentration) and sodium 
dodecyl sulphate (SDS) $(1 \%)$ were added and maintained at $55^{\circ} \mathrm{C}$ with gentle agitation every $10 \mathrm{~min}$ for $2 \mathrm{hrs}$.

To protect the RNA, $10 \mu \mathrm{l}$ of $\beta$-mercaptoethanol were added to $1 \mathrm{ml}$ of RLT plus buffer provided by the kit, $1,550 \mu \mathrm{l}$ of this solution were added to each filter unit and mixed by inversion. The lysate was recovered by using a sterile $5 \mathrm{ml}$ syringe and loaded in three additions onto the DNA columns by centrifuging at $10000 \mathrm{~g}$ for $30 \mathrm{~s}$. DNA and RNA purifications were performed following the manufacturer's guidelines (Qiagen, Germany). The Invitrogen ${ }^{\mathrm{TM}}$ SuperScript ${ }^{\mathrm{TM}}$ VILO $^{\mathrm{TM}}$ cDNA Synthesis Kit (Thermo Fisher Scientific Inc. Carlsbad, CA USA) was utilized to generate cDNA from the RNA extracts. Prior to the reverse transcription, absence of DNA in the RNA extracts was verified by PCR test with general primer sets 341F (5'-CCTACGGGNGGCWGCAG) and 805R (5'GACTACHVGGGTATCTAATCC) (Herlemann et al., 2011) for the prokaryotic 16S rRNA gene, followed by the examination of amplification products on $1 \%$ agarose gel electrophoresis. If a specific band of 1015 bp was observed the RNA extract was treated with 210 DNase.

The final PCR amplification of DNA and cDNA extracts was performed using the primers 515F-Y (5'-GTGYCAGCMGCCGCGG TAA) and 926R (5'CCGYCAATTYMTTTRAGTTT) that encompasses the V4 and V5 hypervariable regions of the 16S rDNA (Parada et al., 2016). Triplicate $10 \mu 1$ reaction mixtures contained $2 \mu \mathrm{g}$ DNA, $5 \mu \mathrm{K}$ KAPA2G Fast HotStart ReadyMix, $0.2 \mu \mathrm{M}$ forward primer and $0.2 \mu \mathrm{M}$ reverse primer. PCR amplification was performed under the following conditions: an initial denaturation step of $95^{\circ} \mathrm{C}$ for $3 \mathrm{~min}$, followed by 30 cycles of denaturation at $95^{\circ} \mathrm{C}$ for $45 \mathrm{~s}$, annealing at $50^{\circ} \mathrm{C}$ for $45 \mathrm{~s}$, and extension at $68^{\circ} \mathrm{C}$ for $90 \mathrm{~s}$, and a final elongation step at $68^{\circ} \mathrm{C}$ for 5 minutes. 
The presence of amplification products was confirmed by $1 \%$ agarose electrophoresis and PCR triplicates were pooled and purified by gel-filtration through-Sephadex G-50 Super Fine resin (Amersham Biosciences, Uppsala, Sweden). Then the purified samples were recovered for sequencing. The 16S rRNA gene amplicons were sequenced via next generation sequencing (Illumina MiSeq $2 \times 250$ bp chemistry on one flow-cell) at the platform GeTPlaGe Genotoul (Toulouse, France). Mock community DNA (LGC standards, UK) was used as a standard for subsequent analyses and considered as a DNA sample for all treatments. In total, 128 samples (32 DNA free-living, 32 DNA particle-attached, 32 cDNA free-living and 32 DNA particle-attached) were sequenced. After the sequencing one sample (cDNA freeliving at M2_1-60m) was discarded, due to low quality in the sequencing.

\subsection{Sequence analysis}

230 The samples obtained in the sequencing run were demultiplexed at the platform GeT-PlaGe Genotoul (Toulouse, France). A total of 5,847,892 sequences were obtained. Processing sequences was conducted with the DADA2 package for R version 1.10.1 (Callahan et al., 2016a), following the pipeline by (Callahan et al., 2016b). Amplicon sequence variants (ASVs) were inferred through the high resolution DADA2 method (Callahan et al., 2016a; Callahan et al., 2017). Primers were trimmed and the sequences were filtered based on their quality using DADA2 (maxEE=2, truncQ=2). Forward reads with a length of $245 \mathrm{bp}$, reverse reads with a length of $210 \mathrm{pb}$, and in total 4,253,969 reads were kept after quality filtering. Error rates were estimated from the data, and inference of the sequence variants was made from the pooled sequences from all the samples. The 1,059,953 unique forward sequences and 1,619,348 reverse unique sequences were pooled to determine the sequence variants, then the forward and reverse sequences were merged and chimeras were removed. We obtained 31, 227 unique ASVs. Taxonomy was assigned based on the SILVA database release 132 at the highest taxonomic level possible (Quast et al., 2013). 
From the 5,847,892 reads we obtained a total of 14,204 ASVs for the 127 samples after singletons removal. The number of reads per sample varied between 2,803 and 48,536. The dataset was randomly subsampled to the lowest number of reads $(2,803)$ per sample with rarefy_even_depth( ) by Phyloseq R package version 1.26.1 (McMurdie and Holmes, 2013). Ordinations were performed with both the complete and subsampled datasets, and the trends observed were consistent for both datasets. To enable the comparison between samples with different numbers of reads, we chose to carry out all analysis using the subsampled dataset. After subsampling, 12,010 ASVs remained in the dataset.

From a total of 127 samples, the prokaryotic community composition was determined in the free-living $(<0.8 \mu \mathrm{m})$ and in the particle-attached $(>0.8 \mu \mathrm{m})$ fractions. DNA-based samples represent the total prokaryotic community and RNA-based samples were used to identify the potentially active members of the community (Blazewicz et al., 2013). Our sequencing data provided access to 12,010 ASVs, of which 8,871 ASVs were obtained for the free-living fraction and 8, 838 ASVs for the particle-attached fraction, and 5,699 ASVs were shared between these fractions.

In order to identify the prokaryotic taxa, the ASVs were compared against the SILVA database release 132 at the highest taxonomic level possible (Quast et al., 2013). The ASVs with the same taxonomy at the order level were pooled for illustration of the relative abundance in the samples. Sequences alignment was performed using MAFFT online service for multiple sequence alignment (Katoh et al., 2019) and the phylogenetic tree was built using PhyML 3.0 online program, based on the maximum likelihood method, with 100 bootstraps and the HKY85 substitution model (Guindon et al., 2010). The phylogenetic tree was visualized with SeaView version 4.7 and saved as a rooted tree (Gouy et al., 2010). The tree was imported in $\mathrm{R}$ with the ape package function read.tree( ). 
To estimate the absolute cell numbers, the ASVs were corrected for copy numbers of the $16 \mathrm{~S}$ rRNA gene per cell per specific taxa obtained from the ribosomal RNA database (Stoddard et al., 2015). Total cell numbers per bacterial group and per Liter were then calculated with 16S rRNA gene relative proportions per group and total cell abundance from flow cytometry.

\subsection{Data analysis}

The difference between total (DNA-based) and potentially active communities (RNA-based) was tested by analysis of similarity (ANOSIM), resulting significant differences $(p=0.001, r=$ 0.23, permutations $=999$ ). Likewise free-living and particle-attached fractions for both, total (DNA) and potentially active (RNA) communities revealed significant differences $(p=0.001$, $\mathrm{r}=0.57$, for DNA-based set and $\mathrm{p}=0.001, \mathrm{r}=0.41$ for RNA-based dataset, permutations $=999$ ). The analyses performed thereafter considers therefore separately the four subsets, free-living and particle attached fractions for both, total (DNA) and potentially active (RNA) community.

To explore the distribution patterns of the prokaryotic communities we applied Non-Metric Multidimensional Scaling (NMDS), based on the dissimilarity matrix of the community structure. The statistical analyses were performed in R 3.5.3 version (R Core Team, 2019), Bray-Curtis dissimilarity matrices were generated via vegdist( ) function using the relative abundance of ASVs in each sample. Subsequently, the matrix was used to build the NMDS ordinations using metaMDS( ) function in the package Vegan (Oksanen et al., 2019). Diversity indices were calculated with phyloseq command estimate_richness( ). ANOSIM was performed to test significant differences in microbial communities between sampling depths and among sites in the surface mixed layer. 
The contribution of individual species (ASVs) to the average Bray-Curtis dissimilarity between the on- and off-plateau groups was obtained using similarity percentage analysis (SIMPER) (Clarke 1993). Station M3 was chosen as the representative off-plateau site and compared to the on-plateau station M2. The analysis was applied to the prokaryotic communities within the wind mixed surface layer. The ASVs with a relative abundance lower than $1 \%$ in at least one sample were discarded prior to the SIMPER analysis. Once the ASVs with significant contribution to the dissimilarity between groups were obtained ( $p$-value $<$ 0.005), the ASVs with relative abundance higher than 5\% in at least one sample were selected for plotting them in a heatmap using the package pheatmap version 1.0.12 for R (Kolde, 2019).

Partial Mantel tests for the free-living and particle attached fractions in both total (DNAbased) and active (RNA-based) prokaryotic community composition, diatom community composition and environmental parameters (temperature, salinity, concentrations of dissolved oxygen, ammonium, nitrite, nitrate, phosphate, silicic acid and DOC), were performed in Vegan using mantel.partial() based on the Pearson correlation method. Prior to correlation analysis, environmental variables were z-score transformed. The amount of variance in prokaryotic community composition explained by diatoms and environmental parameters was estimated as the square of the correlation coefficient $\left(\mathrm{Rho}^{2}\right)$ based on partial Mantel test. The Partial Mantel test was applied to samples in the upper $125 \mathrm{~m}$ water column, for which diatom community composition was available.

Redundancy analysis (RDA) (Legendre \& Legendre, 2012) was applied to evaluate the linkages between the prokaryotic community composition and the environmental parameters in Vegan using rda(). Prior to analysis the environmental variables were z-score transformed 
and Hellinger transformation was applied to the community matrix (Legendre \& Gallagher, 2001). Permutational multivariate analysis of variance in Vegan with adonis() was used to select the significant environmental variables $(p<0.05)$. We used the variance inflation factor (VIF) to determine the linear dependency among variables. We first evaluated all the variables and removed, one at a time, those with a VIF $>10$ from the dataset. Only the selected variables (with a VIF $<10$ ) were used to perform the final RDA analysis. As for the Partial Mantel test, samples in the upper $125 \mathrm{~m}$ were considered.

\section{Results}

\subsection{Environmental conditions}

During late Austral summer the water column was well-stratified, with the wind-mixed surface layer $\left(\mathrm{Z}_{\mathrm{ML}}\right)$ ranging between $49 \mathrm{~m}$ and $62 \mathrm{~m}$ during the first visits of the off-plateau station M4 (M4-1) and of the on-plateau station M2 (M2-1 and M2-2), respectively (Table 1 and Fig. S2). The occurrence of a storm on March $10^{\text {th }}$ lead to a deepening of the $\mathrm{Z}_{\mathrm{ML}}$ that was most pronounced at station M4 $(87 \mathrm{~m})$. A shallow $\mathrm{Z}_{\mathrm{ML}}(27 \mathrm{~m})$ was determined during our visit at station $\mathrm{M} 1$. Temperature in the $\mathrm{Z}_{\mathrm{ML}}$ was lowest at the southernmost station $\mathrm{M} 4\left(4.5^{\circ} \mathrm{C}\right)$ and varied between $4.9^{\circ} \mathrm{C}$ (station M1) and $5.6^{\circ} \mathrm{C}$ (station M3-1) at the other sites (Table 1, Fig. S2). Seasonally low concentrations of Chl $a$ were determined at all sites (Fig. S1), and those in the $\mathrm{Z}_{\mathrm{ML}}$ of the on plateau station M2 (0.27-0.58 $\left.\mu \mathrm{g} \mathrm{L}^{-1}\right)$ were 2-3-fold higher as compared 335 to those at the off-plateau stations M3 (0.14-0.19 $\left.\mu \mathrm{g} \mathrm{L}^{-1}\right)$ and M4 (0.18-0.21 $\left.\mu \mathrm{g} \mathrm{L}^{-1}\right)$ (Fig. 2), and similar to those at station M1 $\left(0.34 \mu \mathrm{g} \mathrm{L}^{-1}\right)(\mathrm{Chl} a$, DOC and prokaryotic abundance for station M1 are illustrated in Fig. S3). Chl $a$ concentrations doubled in the $\mathrm{Z}_{\mathrm{ML}}$ between the $2^{\text {nd }}$ and $3^{\text {rd }}$ visit at the on-plateau site $\mathrm{M} 2$. 
Concentrations of dissolved organic carbon (DOC) were $54.1 \pm 0.6 \mu \mathrm{M}$ in the $\mathrm{Z}_{\mathrm{ML}}$ of station M2 (all visits pooled), as compared to $50.5 \pm 0.7 \mu \mathrm{M}$ at station $\mathrm{M} 3$ and $50.3 \pm 0.8 \mu \mathrm{M}$ at station M4 (Fig. 2). This accumulation of DOC is likely a consequence of the enhanced seasonal phytoplankton activity in Kerguelen plateau waters. Heterotrophic prokaryotic abundance was as high as $1.17 \times 10^{6}$ cells $\mathrm{mL}^{-1}$ in the $\mathrm{Z}_{\mathrm{ML}}$ during our first visit of the on-plateau station $\mathrm{M} 2$, and cell abundances decreased to $0.81 \times 10^{5}$ cells $\mathrm{mL}^{-1}$ and $0.68 \times 10^{5}$ cells $\mathrm{mL}^{-1}$ during the following one and two weeks, respectively. Moderate (from 6.96 to $4.45 \times 10^{5}$ cells $\mathrm{mL}^{-1}$ at M3) and minor decreases (from 5.52 to $5.01 \times 10^{5}$ cells $\mathrm{mL}^{-1}$ at M4) were observed at the offplateau stations over the 2 weeks that separated the visits (Fig. 2). The prokaryotic cell abundance in the $<0.8 \mu \mathrm{m}$ fraction accounted for $89 \pm 11 \%(\mathrm{n}=10)($ Table S1) of the abundance in unfiltered seawater in surface waters at the different sites.

3.2. Vertical and spatial structuring of prokaryotic communities

When considering the entire data set, NMDS ordination revealed a clustering by depth layer, for the total and active prokaryotic communities in both size fractions. Samples collected for the free-living fraction at $10 \mathrm{~m}$ and $60 \mathrm{~m}$, corresponding to the $\mathrm{Z}_{\mathrm{ML}}$ except for station $\mathrm{M} 1$ (Table 1), clustered and were distinct from those of $125 \mathrm{~m}$ and $300 \mathrm{~m}$ (Anosim, $\mathrm{r}=0.69$ for DNA and $r=0.61$ for RNA, $p=0.001$ ) (Fig. 3a for DNA and Fig. S4a for RNA). In the case of the particle-attached fraction, the clustering by depth was less pronounced, but still significant (Anosim, $r=0.58$ for DNA and $r=0.67$ for RNA, $p=0.001$ ) (Fig. $3 b$ for DNA and Fig. S4b for RNA). We determined multiple diversity indices that all revealed an increase with depth in both size-fractions (Table S2) as illustrated for the Shannon index on Table 2.

To identify possible differences in the prokaryotic community composition among sites, we then focused on samples collected in the $\mathrm{Z}_{\mathrm{ML}}$. For the free-living fraction, samples grouped 
according to station (ANOSIM, $r=0.77$ for DNA and $r=0.51$ for RNA, $\mathrm{p}=0.001$ )(Fig. 3a and Fig. 4a). This pattern was again less pronounced for the particle-attached fraction (ANOSIM, $\mathrm{r}=0.62, \mathrm{p}=0.001$ for DNA and $\mathrm{r}=0.41 \mathrm{p}=0.006$ for RNA)(Fig. $3 \mathrm{~b}$ and Fig. S4b). Diversity of the total free-living communities was significantly lower in the $\mathrm{Z}_{\mathrm{ML}}$ of the on-plateau station M2 (Shannon: $4.34 \pm 0.19$ for DNA, $n=6$ ) as compared to that in off plateau waters at stations M1, M3 and M4 (Shannon: 4.86 \pm 0.15 for DNA, $n=9$ )(one-way ANOVA $p<0.001$ ). This trend was, however, not observed for the potentially active free-living communities (Shannon: $5.28 \pm 0.71$ at station $\mathrm{M} 2$ and $5.53 \pm 0.77$ in the off-plateau stations, $\mathrm{n}=9$ ) and the particleattached communities in the DNA and RNA data sets (Table 2 and Table S2).

3.3. Prokaryotic community composition in surface waters

We further explored in more detail the prokaryotic community composition in surface waters $(10 \mathrm{~m})$. The total free-living and particle-attached prokaryotic communities were dominated by Flavobacteriales (relative contributions of 53\% and $64 \%$ in on-plateau waters, $35 \%$ and $36 \%$ in off-plateau waters, respectively) and Rhodobacterales (20\% and $10 \%$ on-plateau, $17 \%$ and $22 \%$ off-plateau, respectively). Cellvibrionales represented $13 \%$ in both size fractions at the on-plateau station (M2), while at the off-plateau stations this order was substantially more abundant in the particle-attached (17\%) than in the free-living fraction (3\%) (Fig. 4; RNA data are illustrated in Fig. S5). Distinct features of the free-living communities in off-plateau waters were the comparably higher contributions of the SAR11 clade, belonging to Pelagibacterales (SAR11, 17-25\%), the SAR86 clade (5-8\%), Thiomicrospirales (2-3\%) and Puniceispirillales (2-4\%). Verrucomicrobiales were present only in the total particle-attached communities and their relative abundances were higher in the off-plateau sites (4-8\%) than in on-plateau waters $(1.3 \%)$. Chitinophagales were detectable only in the particle-attached 
fraction at station $\mathrm{M} 2$ in both the total (2.2\%) and potentially active communities (3.2\%), while Sphingomonadales (2.5\%), Lactobacillales (1.4\%) and Ricksettsiales (1.3\%) appeared to be specific to the total particle-attached communities at station M1. prokaryotic community at the level of ASVs. Interesting information derived at this level of resolution is that in the case of some of the abundant taxonomic groups composed by multiple ASVs, only a few of them were highly abundant. For example, in the total free-living fraction (Fig. S6), Flavobacteriales were composed of 24 ASVs, however, only some of them were more abundant in on-plateau than in off-plateau waters. This was the case for ASV6 Ulvibacter, ASV12 (NS2b marine group), ASV23 (Flavobacteriaceae ASV15 Aurantivirga and ASV36 Polaribacter). By contrast, other Flavobacteriales ASVs were relatively more abundant in off-plateau waters, such as ASV3 Formosa, ASV38 and ASV88 (both NS7 marine group). Another interesting observation is that the most abundant ASV from our dataset, ASV1 OM60(NOR5), belonging to the gammaproteobacterial clade, was only highly abundant in the free-living fraction of the on-plateau station M2, which was not the case for the off-plateau free-living community (Fig. S6). By contrast, the same ASV was highly abundant at all sites in the particle-attached total community, and less abundant in the potentially active community (Fig. S7). Given these patterns obtained from our high resolution results of the community composition, we decided to explore which prokaryotes explained the difference among sites.

\subsection{Identification of site-specific prokaryotes}

To address the question of which prokaryotic taxa explained the difference in the community composition between on- and off-plateau sites (Fig. 3 and Fig. S4), we performed a Simper 
analysis (permutations $=999)$ and selected the ASVs contributing significantly $(\mathrm{p}<0.05)$ to the differences between stations at $10 \mathrm{~m}$ and $60 \mathrm{~m}$. Because seasonal $\mathrm{Chl} a$ concentrations were lower at M3 as compared to M4 (Fig. S1) we chose station M3 as a representative offplateau site for the further comparison with station M2. In order to simplify the visualization

415 of the information, we considered only highly abundant ASVs (relative abundance $>5 \%$ in at least one sample).

A total of 9 and 8 highly abundant ASVs, respectively, contributed significantly to the differences in the total (DNA) or potentially active (RNA) free-living communities between stations M2 and M3 at $10 \mathrm{~m}$ (Fig. 5; results for $60 \mathrm{~m}$ are shown in Fig. S8); among those, 5 420 ASVs were shared between the DNA and RNA datasets. The 9 and 8 ASVs explained each $24 \%$ and $8 \%$ of the differences among sites in the total and potentially active free-living communities, respectively. For the particle-attached communities 6 and 3 ASVs contributed significantly to the respective differences and these ASVs explained $28 \%$ and $4 \%$ of the observed variability. Two ASVs (ASV5 and ASV15) significantly contributed to the differences in both size fractions of the DNA and RNA dataset.

ASVs that had higher relative abundances at station M2 as compared to station M3 belonged to the OM60 group (NOR5 clade, Halieaceae ASV1), the Flavobacteriaceae NS5 marine group (ASV11), the genera Aurantivirga (ASV15) and Ulvibacter (ASV6), and ASV5 and ASV23 (not identified on the genus level), the Saprospiraceae (ASV33) and the Cryomorphaceae NS10 marine group (ASV52). The Pirellulaceae genus Blastopirellula (ASV8) had low relative abundances in the free-living fraction at station M2 $(<0.1 \%)$ and this ASV was absent from station M3. ASVs with higher relative abundances at station M3 as compared to station M2 were the Flavobacteriaceae genus Formosa (ASV3), and the Rhodobacteraceae genera Planktomarina (ASV16) and Loktanella (ASV18). Contrasting patterns were observed for the SAR11 clade (ASV9) that had higher relative abundances in 
the total free-living communities at station M3, but a higher contribution to the potentially active free-living communities at station M2.

\subsection{Changes in the absolute abundance of major taxa}

To explore the question of whether the pronounced decrease in bulk prokaryotic abundance between repeated visits at station M2 (Fig. 2) were due to changes in specific taxa, we estimated the absolute abundances of ASVs, grouped at the order level, using previously published rRNA operon copy numbers (Stoddard et al., 2015). Our results reveal an increase in the abundance of SAR11 from the first to the third visit (by up to 150\%) at station M2 at 10 $\mathrm{m}$ and a decrease in the abundance of all other considered taxa by on average $48 \pm 12 \%$ and $65 \pm 10 \%$ after one and two weeks, respectively (Fig. 6; RNA results are shown in Fig. S9).

\subsection{Linking prokaryotic community composition to biotic and abiotic factors}

The combined set of abiotic environmental parameters and diatom community composition, as determined by microscopic observations (Lafond et al., 2020), could each explain changes

450 in the total and potentially active prokaryotic communities in both size fractions and all depth layers ( $\mathrm{p}<0.05$; partial Mantel test; Table S3). Environmental parameters could explain 12\% and $16 \%$ of the spatio-temporal changes in the total and potentially active free-living communities, respectively, and $9 \%$ and $10 \%$ of the respective particle-attached communities. Diatoms could explain $36 \%$ and $28 \%$ of the changes in the total and active free-living communities, respectively, and $20 \%$ and $14 \%$ of the total and active particle-attached communities. An additional RDA-analysis revealed a clear distinction in on and off-plateau prokaryotic communities in the $\mathrm{Z}_{\mathrm{ML}}$ while samples from $125 \mathrm{~m}$ of all sites grouped (Fig. S10). Among the environmental parameters tested (Table S4), significant predictors of the 
community composition were temperature, salinity, dissolved oxygen, ammonium, nitrite and

DOC. In the $\mathrm{Z}_{\mathrm{ML}}$, DOC was a significant predictor for the free-living $(\mathrm{p}=0.039)$ and particleattached fraction $(\mathrm{p}=0.01)$, and this was the case for salinity and the communities at $125 \mathrm{~m}$ $(\mathrm{p}=0.001$ and $\mathrm{p}=0.007$, respectively).

\section{Discussion}

465 We observed distinct prokaryotic communities in surface waters above the central Kerguelen plateau as compared to those in off-plateau waters during the post-bloom period in late Austral summer. These findings add to observations from early spring (Landa et al., 2016) and summer (West et al., 2008; Obernosterer et al., 2011) corresponding to the onset, peak and early decline of the phytoplankton bloom. A similar spatial structuring was also reported

470 for diatoms (Armand et al., 2008; Lasbleiz et al., 2016; Lafond et al., 2020), non-diatom phytoplankton and protists (Georges et al., 2014; Irion et al., 2020; Sassenhagen et al., 2020) during the different bloom phases, and indicates a seasonally persistent influence of natural Fe fertilization on unicellular plankton communities. We discuss in the following the potential role of abiotic and biotic factors to better understand this pattern and the role of specific taxa

475 in the microbial cycling of elements.

\subsection{Post-bloom conditions and bulk prokaryotic features}

A distinct feature of the surface waters above the Kerguelen plateau in late summer is the accumulation of DOC. Both, the Partial Mantel test and RDA analysis indicated that DOC concentrations had significant influence on the prokaryotic community composition in the wind mixed surface layer (Table S3, Fig. S10). The higher DOC concentrations likely result from the seasonally enhanced autotrophic activity, the excretion of phytoplankton-derived organic matter as cells become less active when entering a senescent stage (Myklestad et al., 
1989; Barofsky et al., 2009), and the release of DOC due to grazing (i.e. 'sloppy-feeding') (Steinberg and Landry, 2017), leading to a relief of organic carbon limitation (Obernosterer et al., 2015). Besides the quantity, the composition of organic matter could differ among on- and off-plateau sites as a consequence of the varying productivity regimes and thereby contribute to shaping the community composition. The high similarity among prokaryotes at the offplateau sites, despite their location in different water masses supports this idea.

Seasonal observations in Kerguelen plateau surface waters could provide some insights on organic matter availability and its influence on community composition. Prokaryotic growth rates determined during the post-bloom period $\left(0.04\right.$ to $\left.0.15 \mathrm{~d}^{-1}\right)($ Christaki et al., 2020) were in the same range as those in early spring $\left(0.025\right.$ to $\left.0.12 \mathrm{~d}^{-1}\right)$ (Christaki et al., 2014), and lower than those determined in summer $\left(0.22\right.$ to $\left.0.47 \mathrm{~d}^{-1}\right)$ (Christaki et al. 2008), suggesting an increase in organic matter availability during the peak and early decline of the bloom. The seasonal modifications in organic matter availability were paralleled by changes in prokaryotic diversity. In late summer, the Shannon index in Kerguelen plateau surface waters was in the same range to those determined in early spring at the same site (about 4.5), while a drop to 2.5 was observed following the peak of the spring bloom (Liu et al., 2020). This latter observation points to the dominance of a few fast-growing opportunists taking advantage of the labile organic matter during the peak and just after the bloom (Liu et al., 2020), while the utilization of the post-bloom organic matter pool appears to be attributable to a large number of taxa with well-defined ecological niches.

\subsection{Abundant prokaryotic taxa in Kerguelen plateau waters in late summer} Flavobacteriaceae were present at all sites, but accounted for up to $53 \%$ and $63 \%$ of relative abundance of the free-living and particle-attached total community in Kerguelen plateau surface waters. Members of this family contain a diverse repertoire of enzymatic capabilities for the degradation of complex compounds, including those of phytoplankton origin 
(Kappelmann et al., 2019). Substrate preferences vary among taxa (Xing et al., 2015; Krüger et al., 2019) leading to the niche partitioning among diverse members of this family, including the late summer community in Kerguelen plateau waters (Sun et al., in press). Aurantivirga explained differences between on- and off-plateau waters in the total and potentially active communities in both fractions. Aurantivirga was shown to account for about $10 \%$ throughout the summer period in Kerguelen plateau waters (Liu et al., 2020). The key role of Aurantivirga could be explained by the high number of polysaccharide uptake loci (PULs) and the diverse substrate spectra for glycan degradation reported for members of this genus (Krüger et al., 2019). On the contrary, the Flavobacteriaceae genus Formosa had higher abundances in off plateau waters, and thus appears to be adapted to a more oligotrophic-type lifestyle. was among the most abundant taxa of our dataset and this ASV contributed significantly to the differences in communities between on- and off plateau surface waters. This contrasts observations from November through February when the relative abundance of this group remained low $(<2 \%)$ in plateau waters (Liu et al., 2020). This clade comprises aerobic anoxygenic phototrophs and members associated to aggregates where they thrive under suboxic conditions (Fuchs et al., 2007). In the present study, this ASV was highly abundant in the total particle-attached community (DNA-based) at all sites (Fig. S8). Another interesting feature is the potential implication of members of this clade in the degradation of the sulphur compound dimethylsulfoniopropionate (DMSP) (Nowinski et al., 2019; Steiner et al., 2019). Kerguelen surface waters were not enriched in particulate DMSP in summer during the peak of the diatom-dominated bloom (Belviso et al., 2008). However, the shift to non-diatom phytoplankton, including DMSP producers such as Haptophytes (Schoemann et al., 2005), 
dominated by Phaeocystis Antarctica in the study region (Irion et al., 2020) could suggest a different scenario in late summer. The changes in the late summer light regime due to the low phytoplankton biomass in the well-stratified shallow surface mixed layer and changes in organic carbon sources provided by non-diatom phytoplankton could have led to the success of the OM60 group. One ASV belonging to Saprospiraceae (Chitinophagales) was highly abundant in the particle-attached community, but accounted for $<1 \%$ on a seasonal scale (Liu et al., 2020). Saprospiraceae were shown to respond in terms of relative abundance in incubation experiments enriched in alginate particles (Mitulla et al., 2016). The associated glycolytic abilities could be advantageous for members of this family in the occupation of a specific substrate niche, provided for example by aggregates of detrital and non-living cells that contributed to up to $65 \%$ to total particulate organic carbon in late summer in Kerguelen plateau surface waters (Lafond et al., 2020).

\subsection{Potential role of biotic interactions in shaping community composition} Diatom assemblages explained a substantial part of the changes in prokaryotic community composition, despite their lower biomass as compared to other bloom phases (Irion et al., 2020; Lafond et al., 2020). Diatoms were shown to be drivers of the prokaryotic community composition in the Southern Ocean on spatial (Liu et al., 2019) and seasonal scales (Liu et al., 2020), with diatom-derived DOM playing an important role in spring (Landa et al., 2016). In late Austral summer, Corethron inerme accounted for $60-80 \%$ of total diatom biomass and it was among the most actively silicifying species in on-plateau waters (Lafond et al., 2020). On a seasonal scale, $C$. inerme had a large number of positive correlations with free-living and attached prokaryotes in Kerguelen plateau waters (Liu et al., 2020). These included taxa identified in the present study as being more abundant in on-plateau waters, in particular those belonging to Flavobacteriaceae and Cryomorphaceae. Another diatom abundant in Austral 
summer in the study region is Rhizosolenia spp. (Armand et al., 2008; Blain et al., 2020; Lafond et al., 2020). This diatom revealed strong positive correlations with the Roseobacter genus Loktanella (Liu et al., 2020), a taxon that was highly abundant in off-plateau waters in the particle-attached fraction in the present study. Corethron spp. and Rhizosolenia spp. are both large diatoms (about $20 \mu \mathrm{m}$ equivalent spherical radius, ESR), and could thus present habitats for taxa with a particle-attached lifestyle.

The marked decrease in bulk prokaryotic abundances during the consecutive visits at the onplateau station was predominantly due to grazing by heterotrophic nanoflagellates (Christaki et al., 2020). This raises the question of whether selective ingestion could have influenced prokaryotic community composition. Our observations of a narrow range in the decrease of taxon-specific cells over time suggests grazing to be non-selective, but rather a function of the cell abundance and thus the encounter rate of a given taxon. In addition, prokaryotic community composition did not change substantially between visits at station M2, despite the high grazing activity. While a number of experimental studies carried out with freshwater communities demonstrate the influence of grazers on prokaryotic community composition (see review by Hahn and Höfle, 2001), experimental studies have revealed positive (Teira et al., 2019) or no marked effects (Yokokawa and Nagata, 2005; Landa et al., 2014; Baltar et al., 2016) of the presence of grazers on marine prokaryotic diversity and composition. Our observations appear to be in line with these latter reports and suggest a minor influence of grazers on the temporal changes of the prokaryotic community composition in Kerguelen plateau waters.

\subsection{Conclusions}

Our observations from late Austral summer add another piece to the pictures obtained during early spring and summer and thereby extend our previous conclusions on the pronounced 
effect of natural Fe fertilization on prokaryotic community composition to the post-bloom period. The accumulation of DOC, as a consequence of the high seasonal productivity in Kerguelen plateau waters, together with the potential prokaryote-diatom interactions

585 contribute to the build-up of prokaryote bulk biomass and to their taxonomic composition. The capabilities in the access to different forms of Fe, key for the processing of organic matter, vary among prokaryotic groups (Debeljak et al., 2019) and likely play an additional role in shaping microbial communities. Our results suggest that the most abundant prokaryotic taxa identified as specific to the productive Kerguelen plateau surface waters in 590 late summer contribute to the transfer of organic matter to heterotrophic nanoflagellates (Christaki et al., 2020) and potentially higher trophic levels. 


\section{References}

595 Agogué, H., Lamy, D., Neal, P.R., Sogin, M.L., and Herndl, G.J. (2011) Water massspecificity of bacterial communities in the North Atlantic revealed by massively parallel sequencing. Molecular Ecology 20: 258-274.

Armand, L.K., Cornet-Barthaux, V., Mosseri, J., and Quéguiner, B. (2008) Late summer diatom biomass and community structure on and around the naturally iron-fertilised 600 Kerguelen Plateau in the Southern Ocean. Deep Sea Research Part II: Topical Studies in Oceanography 55: 653-676.

Bachmann, J., Heimbach, T., Hassenrück, C., Kopprio, G.A., Iversen, M.H., Grossart, H.P., and Gärdes, A. (2018) Environmental Drivers of Free-Living vs. Particle-Attached Bacterial Community Composition in the Mauritania Upwelling System. Front Microbiol 9: 2836.

605 Baltar, F., Palovaara, J., Unrein, F., Catala, P., Horňák, K., Šimek, K., et al. (2016) Marine bacterial community structure resilience to changes in protist predation under phytoplankton bloom conditions. The ISME Journal 10: 568-581.

Barofsky, A., Vidoudez, C., and Pohnert, G. (2009) Metabolic profiling reveals growth stage variability in diatom exudates. Limnology and Oceanography: Methods 7: 382-390.

610 Belviso, S., Bopp, L., Mosseri, J., Tedetti, M., Garcia, N., Griffiths, B., et al. (2008) Effect of natural iron fertilisation on the distribution of DMS and DMSP in the Indian sector of the Southern Ocean. Deep Sea Research Part II: Topical Studies in Oceanography 55: 893-900.

Benner, R. and Strom, M. (1993) A critical evaluation of the analytical blank associated with DOC measurements by high-temperature catalytic oxidation. Marine Chemistry 41: 153-160. 
615 Blain, S., Quéguiner, B., Armand, L., Belviso, S., Bombled, B., Bopp, L., et al. (2007) Effect of natural iron fertilization on carbon sequestration in the Southern Ocean. Nature 446: 10701074.

Blain, S., Rembauville, M., Crispi, O., and Obernosterer, I. (2020) Synchronized autonomous sampling reveals coupled pulses of biomass and export of morphologically different diatoms 620 in the Southern Ocean. Limnology and Oceanography n/a:

Blazewicz, S.J., Barnard, R.L., Daly, R.A., and Firestone, M.K. (2013) Evaluating rRNA as an indicator of microbial activity in environmental communities: limitations and uses. The ISME Journal 7: 2061-2068.

Buchan, A., LeCleir, G.R., Gulvik, C.A., and González, J.M. (2014) Master recyclers: 625 features and functions of bacteria associated with phytoplankton blooms. Nature Reviews Microbiology 12: 686-698.

Bunse, C. and Pinhassi, J. (2017) Marine Bacterioplankton Seasonal Succession Dynamics. Trends in Microbiology 25: 494-505.

Callahan, B.J., McMurdie, P.J., and Holmes, S.P. (2017) Exact sequence variants should replace operational taxonomic units in marker-gene data analysis. The ISME Journal 11: 2639-2643.

Callahan, B. J, McMurdie, P.J., Rosen, M.J., Han, A.W., Johnson, A.J.A., and Holmes, S.P. (2016a) DADA2: High resolution sample inference from Illumina amplicon data. Nat Methods 13: 581-583. 
635 Callahan, B. J., Sankaran, K., Fukuyama, J.A., McMurdie, P.J., and Holmes, S.P. (2016b)

Bioconductor Workflow for Microbiome Data Analysis: from raw reads to community analyses. F1000Res 5: 1492.

Christaki, U., Gueneugues, A., Liu, Y., Blain, S., Catala, P., Colombet, J., et al. (2020) Seasonal microbial food web dynamics in contrasting Southern Ocean productivity regimes. 640 Limnology and Oceanography n/a:

Christaki, U., Lefèvre, D., Georges, C., Colombet, J., Catala, P., Courties, C., et al. (2014) Microbial food web dynamics during spring phytoplankton blooms in the naturally ironfertilized Kerguelen area (Southern Ocean). Biogeosciences 11: 6739-6753.

Christaki, U., Obernosterer, I., Van Wambeke, F., Veldhuis, M., Garcia, N., and Catala, P. 645 (2008) Microbial food web structure in a naturally iron-fertilized area in the Southern Ocean (Kerguelen Plateau). Deep Sea Research Part II: Topical Studies in Oceanography 55: 706719.

Clarke, K.R. (1993) Non-parametric multivariate analyses of changes in community structure. Austral Ecol 18: 117-143.

650 Debeljak, P., Toulza, E., Beier, S., Blain, S., and Obernosterer, I. (2019) Microbial iron metabolism as revealed by gene expression profiles in contrasted Southern Ocean regimes. Environmental Microbiology 21: 2360-2374.

Ducklow, H.W., Hansell, D.A., and Morgan, J.A. (2007) Dissolved organic carbon and nitrogen in the Western Black Sea. Marine Chemistry 11. 
655 Fuchs, B.M., Spring, S., Teeling, H., Quast, C., Wulf, J., Schattenhofer, M., et al. (2007) Characterization of a marine gammaproteobacterium capable of aerobic anoxygenic photosynthesis. PNAS 104: 2891-2896.

Georges, C., Monchy, S., Genitsaris, S., and Christaki, U. (2014) Protist community composition during early phytoplankton blooms in the naturally iron-fertilized Kerguelen area 660 (Southern Ocean). Biogeosciences 11: 5847-5863.

Ghiglione, J.F., Mevel, G., Pujo-Pay, M., Mousseau, L., Lebaron, P., and Goutx, M. (2007) Diel and Seasonal Variations in Abundance, Activity, and Community Structure of ParticleAttached and Free-Living Bacteria in NW Mediterranean Sea. Microb Ecol 54: 217-231.

Gouy, M., Guindon, S., and Gascuel, O. (2010) SeaView Version 4: A Multiplatform 665 Graphical User Interface for Sequence Alignment and Phylogenetic Tree Building. Mol Biol Evol 27: 221-224.

Guindon, S., Dufayard, J.-F., Lefort, V., Anisimova, M., Hordijk, W., and Gascuel, O. (2010) New Algorithms and Methods to Estimate Maximum-Likelihood Phylogenies: Assessing the Performance of PhyML 3.0. Systematic Biology 59: 307-321.

Hahn, M.W. and Höfle, M.G. (2001) Grazing of protozoa and its effect on populations of aquatic bacteria. FEMS Microbiology Ecology 35: 113-121.

Herlemann, D.P., Labrenz, M., Jürgens, K., Bertilsson, S., Waniek, J.J., and Andersson, A.F. (2011) Transitions in bacterial communities along the $2000 \mathrm{~km}$ salinity gradient of the Baltic Sea. The ISME Journal 5: 1571-1579. 
675 Irion, S., Jardillier, L., Sassenhagen, I., and Christaki, U. (2020) Marked spatiotemporal variations in small phytoplankton structure in contrasted waters of the Southern Ocean (Kerguelen area). Limnology and Oceanography 65: 2835-2852.

Kappelmann, L., Krüger, K., Hehemann, J.-H., Harder, J., Markert, S., Unfried, F., et al. (2019) Polysaccharide utilization loci of North Sea Flavobacteriia as basis for using SusC/Dprotein expression for predicting major phytoplankton glycans. The ISME Journal 13: 76-91.

Katoh, K., Rozewicki, J., and Yamada, K.D. (2019) MAFFT online service: multiple sequence alignment, interactive sequence choice and visualization. Brief Bioinform 20: 11601166.

Kolde R. (2019). pheatmap: Pretty Heatmaps. R package version 1.0.12. https://CRAN.R685 project.org/package $=$ pheatmap

Krüger, K., Chafee, M., Ben Francis, T., Glavina del Rio, T., Becher, D., Schweder, T., et al. (2019) In marine Bacteroidetes the bulk of glycan degradation during algae blooms is mediated by few clades using a restricted set of genes. The ISME Journal 13: 2800-2816.

Lafond, A., Leblanc, K., Legras, J., Cornet, V., and Quéguiner, B. (2020) The structure of 690 diatom communities constrains biogeochemical properties in surface waters of the Southern Ocean (Kerguelen Plateau). Journal of Marine Systems 212: 103458.

Landa, M., Blain, S., Christaki, U., Monchy, S., and Obernosterer, I. (2016) Shifts in bacterial community composition associated with increased carbon cycling in a mosaic of phytoplankton blooms. The ISME Journal 10: 39-50.

695 Landa, M., Cottrell, M.T., Kirchman, D.L., Kaiser, K., Medeiros, P.M., Tremblay, L., et al. (2014) Phylogenetic and structural response of heterotrophic bacteria to dissolved organic 
matter of different chemical composition in a continuous culture study. Environmental Microbiology 16: 1668-1681.

Lasbleiz, M., Leblanc, K., Armand, L.K., Christaki, U., Georges, C., Obernosterer, I., and 700 Quéguiner, B. (2016) Composition of diatom communities and their contribution to plankton biomass in the naturally iron-fertilized region of Kerguelen in the Southern Ocean. FEMS Microbiology Ecology 92:.

Legendre, P. and Gallagher, E.D. (2001) Ecologically meaningful transformations for ordination of species data. Oecologia 129: 271-280.

705 Legendre, P. and Legendre, L. (2012) Canonical analysis. In Developments in Environmental Modelling. Elsevier, pp. 625-710.

Liu, Y., Blain, S., Crispi, O., Rembauville, M., and Obernosterer, I. (2020) Seasonal dynamics of prokaryotes and their associations with diatoms in the Southern Ocean as revealed by an autonomous sampler. Environmental Microbiology 22: 3968-3984.

710 Liu, Y., Debeljak, P., Rembauville, M., Blain, S., and Obernosterer, I. (2019) Diatoms shape the biogeography of heterotrophic prokaryotes in early spring in the Southern Ocean. Environmental Microbiology 21: 1452-1465.

McMurdie, P.J. and Holmes, S. (2013) phyloseq: An R Package for Reproducible Interactive Analysis and Graphics of Microbiome Census Data. PLOS ONE 8: e61217.

715 Mitulla, M., Dinasquet, J., Guillemette, R., Simon, M., Azam, F., and Wietz, M. (2016) Response of bacterial communities from California coastal waters to alginate particles and an alginolytic Alteromonas macleodii strain. Environmental Microbiology 18: 4369-4377. 
Myklestad, S., Holm-Hansen, O., Vårum, K.M., and Volcani, B.E. (1989) Rate of release of extracellular amino acids and carbohydrates from the marine diatom Chaetoceros affinis. Journal of Plankton Research 11: 763-773.

Nowinski, B., Motard Côté, J., Landa, M., Preston, C.M., Scholin, C.A., Birch, J.M., et al. (2019) Microdiversity and temporal dynamics of marine bacterial dimethylsulfoniopropionate genes. Environmental Microbiology 21: 1687-1701.

Obernosterer, I., Catala, P., Lebaron, P., and West, N.J. (2011) Distinct bacterial groups contribute to carbon cycling during a naturally iron fertilized phytoplankton bloom in the Southern Ocean. Limnology and Oceanography 56: 2391-2401.

Obernosterer, I., Fourquez, M., and Blain, S. (2015) Fe and C co-limitation of heterotrophic bacteria in the naturally fertilized region off the Kerguelen Islands. Biogeosciences 12: 19831992.

Oksanen, J., Blanchet, F.G., Kindt, R., Legendre, P., Minchin, P.R., O'Hara, R.B., et al. (2019) vegan: community ecology package. R Package Version 2.5-6. https:/CRAN.Rproject.org/package= $=$ egan

Ortega-Retuerta, E., Joux, F., Jeffrey, W.H., and Ghiglione, J.F. (2013) Spatial variability of particle-attached and free-living bacterial diversity in surface waters from the Mackenzie River to the Beaufort Sea (Canadian Arctic). Biogeosciences 10: 2747-2759.

Parada, A.E., Needham, D.M., and Fuhrman, J.A. (2016) Every base matters: assessing small subunit rRNA primers for marine microbiomes with mock communities, time series and global field samples. Environmental Microbiology 18: 1403-1414. 
Pauthenet, E., Roquet, F., Madec, G., Guinet, C., Hindell, M., McMahon, C.R., et al. (2018)

Seasonal Meandering of the Polar Front Upstream of the Kerguelen Plateau. Geophysical Research Letters 45: 9774-9781.

Quast, C., Pruesse, E., Yilmaz, P., Gerken, J., Schweer, T., Yarza, P., et al. (2013) The SILVA ribosomal RNA gene database project: improved data processing and web-based tools. Nucleic Acids Res 41: D590-D596.

745 R Core Team (2019). R: A language and environment for statistical computing. R Foundation for Statistical Computing, Vienna, Austria. URL https://www.R-project.org/

Ras, J., Claustre, H., and Uitz, J. (2008) Spatial variability of phytoplankton pigment distributions in the Subtropical South Pacific Ocean: comparison between in situ and predicted data. 17

750 Rieck, A., Herlemann, D.P.R., Jürgens, K., and Grossart, H.-P. (2015) Particle-Associated Differ from Free-Living Bacteria in Surface Waters of the Baltic Sea. Front Microbiol 6:.

Sassenhagen, I., Irion, S., Jardillier, L., Moreira, D., and Christaki, U. (2020) Protist Interactions and Community Structure During Early Autumn in the Kerguelen Region (Southern Ocean). Protist 171: 125709.

755 Schoemann, V., Becquevort, S., Stefels, J., Rousseau, V., and Lancelot, C. (2005) Phaeocystis blooms in the global ocean and their controlling mechanisms: a review. Journal of Sea Research 53: 43-66.

Steiner, P.A., Sintes, E., Simó, R., Corte, D.D., Pfannkuchen, D.M., Ivančić, I., et al. (2019) Seasonal dynamics of marine snow-associated and free-living demethylating bacterial 
communities in the coastal northern Adriatic Sea. Environmental Microbiology Reports 11: 699-707.

Steinberg, D.K. and Landry, M.R. (2017) Zooplankton and the Ocean Carbon Cycle. Annu Rev Mar Sci 9: 413-444.

Stoddard, S.F., Smith, B.J., Hein, R., Roller, B.R.K., and Schmidt, T.M. (2015) rrnDB: 765 improved tools for interpreting rRNA gene abundance in bacteria and archaea and a new foundation for future development. Nucleic Acids Res 43: D593-D598.

Sun, Y., P. Debeljak and I. Obernosterer (in press) Microbial iron and carbon metabolism as revealed by functional diversity in the Southern Ocean. ISMEJ DOI:10.1038/s41396-02100973-3

770 Teeling, H., Fuchs, B.M., Becher, D., Klockow, C., Gardebrecht, A., Bennke, C.M., et al. (2012) Substrate-Controlled Succession of Marine Bacterioplankton Populations Induced by a Phytoplankton Bloom. Science 336: 608-611.

Teira, E., Logares, R., Gutiérrez Barral, A., Ferrera, I., Varela, M.M., Morán, X.A.G., and Gasol, J.M. (2019) Impact of grazing, resource availability and light on prokaryotic growth 775 and diversity in the oligotrophic surface global ocean. Environmental Microbiology 21: $1482-1496$.

West, N.J., Obernosterer, I., Zemb, O., and Lebaron, P. (2008) Major differences of bacterial diversity and activity inside and outside of a natural iron-fertilized phytoplankton bloom in the Southern Ocean. Environmental Microbiology 10: 738-756. 
780 Xing, P., Hahnke, R.L., Unfried, F., Markert, S., Huang, S., Barbeyron, T., et al. (2015) Niches of two polysaccharide-degrading Polaribacter isolates from the North Sea during a spring diatom bloom. The ISME Journal 9: 1410-1422.

Yokokawa, T. and Nagata, T. (2005) Growth and Grazing Mortality Rates of Phylogenetic Groups of Bacterioplankton in Coastal Marine Environments. Appl Environ Microbiol 71: $785 \quad 6799-6807$

Zhang, R., Liu, B., Lau, S.C.K., Ki, J.-S., and Qian, P.-Y. (2007) Particle-attached and freeliving bacterial communities in a contrasting marine environment: Victoria Harbor, Hong Kong. FEMS Microbiology Ecology 61: 496-508.

Zhang, Y., Jing, H., and Peng, X. (2020) Vertical shifts of particle-attached and free-living 790 prokaryotes in the water column above the cold seeps of the South China Sea. Marine Pollution Bulletin 156: 111230. 
Figure Legends

Figure 1. Map of the MOBYDICK station locations. Surface chlorophyll concentrations are from Global Ocean Satellite Observations (Copernicus-GlobColour). Reprocessed data are provided by Copernicus Marine Service. Chlorophyll concentrations are the monthly mean for March 2018 at a resolution of $4 \mathrm{~km}$. The black lines denote $1000 \mathrm{~m}$ bathymetry.

Figure 2. Vertical profiles of $\mathrm{Chl} a$, DOC and prokaryotic abundance at the on-plateau station M2 and the off-plateau stations M3 and M4. Chla and prokaryotic abundances are shown for each visit, DOC concentration is given as the mean of the repeated visits. Data for station M1 are shown in Fig. S3.

Figure 3. Non-Metric Multidimensional Scaling (NMDS) of total (DNA) prokaryotic communities in the (a) free-living and (b) particle-attached fraction from all depth layers based on Bray-Curtis Dissimilarity. Sample depths are indicated by color, sampling sites by symbol and the number of visit is indicated with a number next to the respective symbol (see Table 1 for more information about sampling scheme.)

Figure 4. Relative abundance of total (DNA) free-living (FL) and particle-attached (PA) taxa grouped at order level in surface waters $(10 \mathrm{~m})$. For stations M2, M3 and M4 the relative abundances of the first visit are shown.

Figure 5. Relative abundance of ASVs that contribute significantly $(p<0.05)$ to the 810 dissimilarity between stations M2 and M3 (SIMPER analysis) at 10m. Asterisk highlight significant differences for a given ASV between sites, in either the free-living or particleattached fractions, for the total (DNA) or potentially active (RNA) communities. Only the ASVs with relative abundance $>5 \%$ in at least one of the samples are shown. Note that the 
ASVs that contribute to the difference among sites are not always the same for the total and the active communities

Figure 6. Changes in the absolute abundance of dominant taxa (DNA, free-living fraction) between the first and the second (M2_3) and the first and the third (M2_3) visit at station M2 at $10 \mathrm{~m}$. Deviations are given as percent; positive and negative values indicate an increase and a decrease, respectively, in abundance over the repeated visits at station M2. The deviation was calculated based on a formula published in Agogué et al. (2011).

Sequencing data. Demultiplexed sequence files are available in NCBI under accession number PRJNA679029.

\section{Acknowledgments}

We thank B. Quéguiner, the PI of the MOBYDICK project, for providing us the opportunity 825 to participate to this cruise, and the captain and crew of the $R / V$ Marion Dufresne for their enthusiasm and support aboard during the MOBYDICK- THEMISTO cruise (https://doi.org/10.17600/18000403). This work was supported by the French oceanographic fleet ("Flotte océanographique française"), the French ANR (“Agence Nationale de la Recherche", AAPG 2017 program, MOBYDICK Project number : ANR-17-CE01-0013), and the French Research program of INSU-CNRS LEFE/CYBER ("Les enveloppes fluides et l'environnement" - “Cycles biogéochimiques, environnement et ressources"). We thank P. Catala for flow cytometry analyses. We are grateful to A. Lafond and J. Legras for sharing with us the diatom species abundances obtained by microscopic observations. We thank the GenoToul Bioinformatics platform (http://bioinfo.genotoul.fr/) for providing computing resources. Y.L. was supported by the China Scholarship Council (CSC; No. 201606330072). Three reviewers provided constructive comments that helped improve a previous version of the manuscript. 


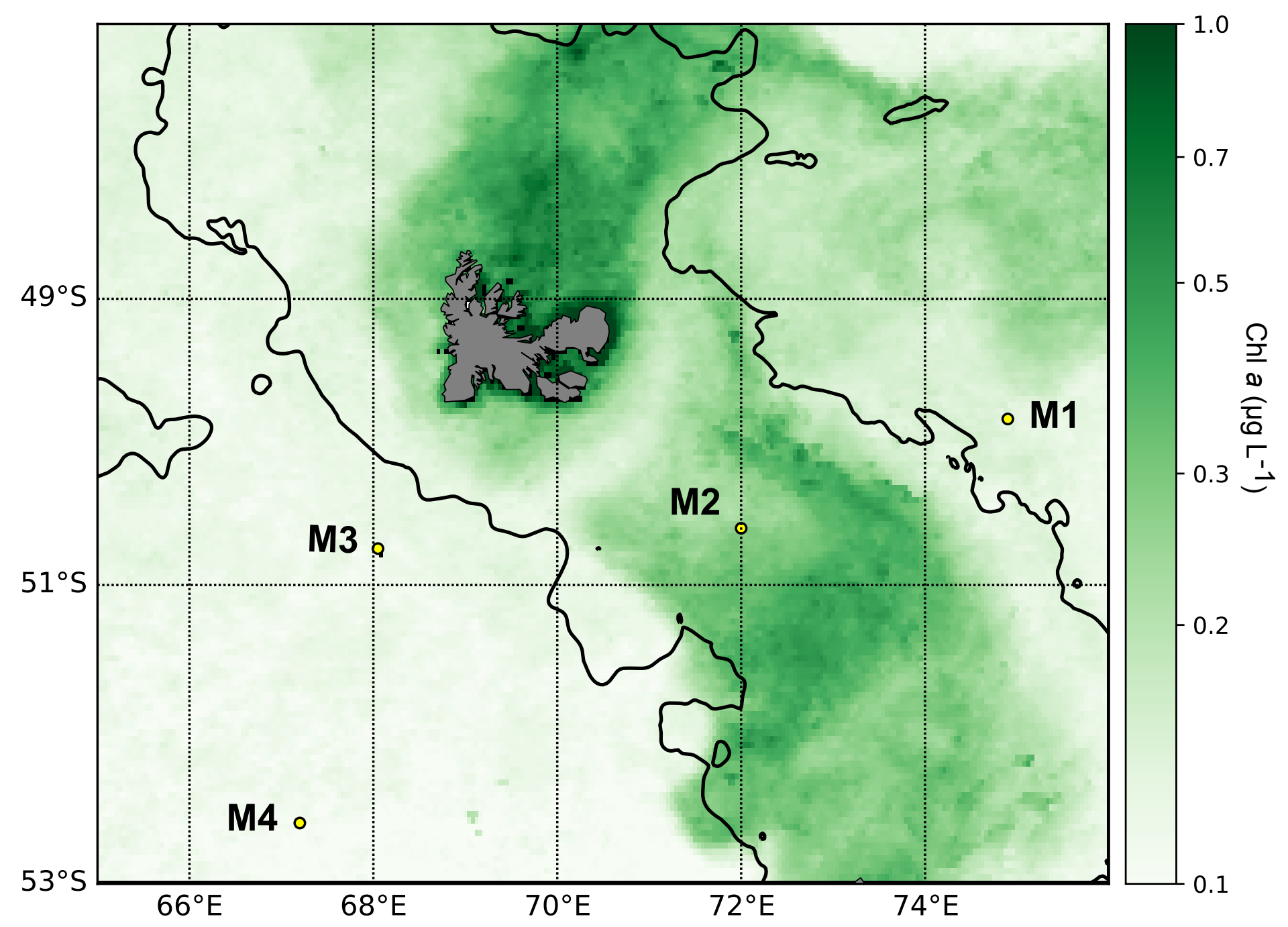

Fig. 1 

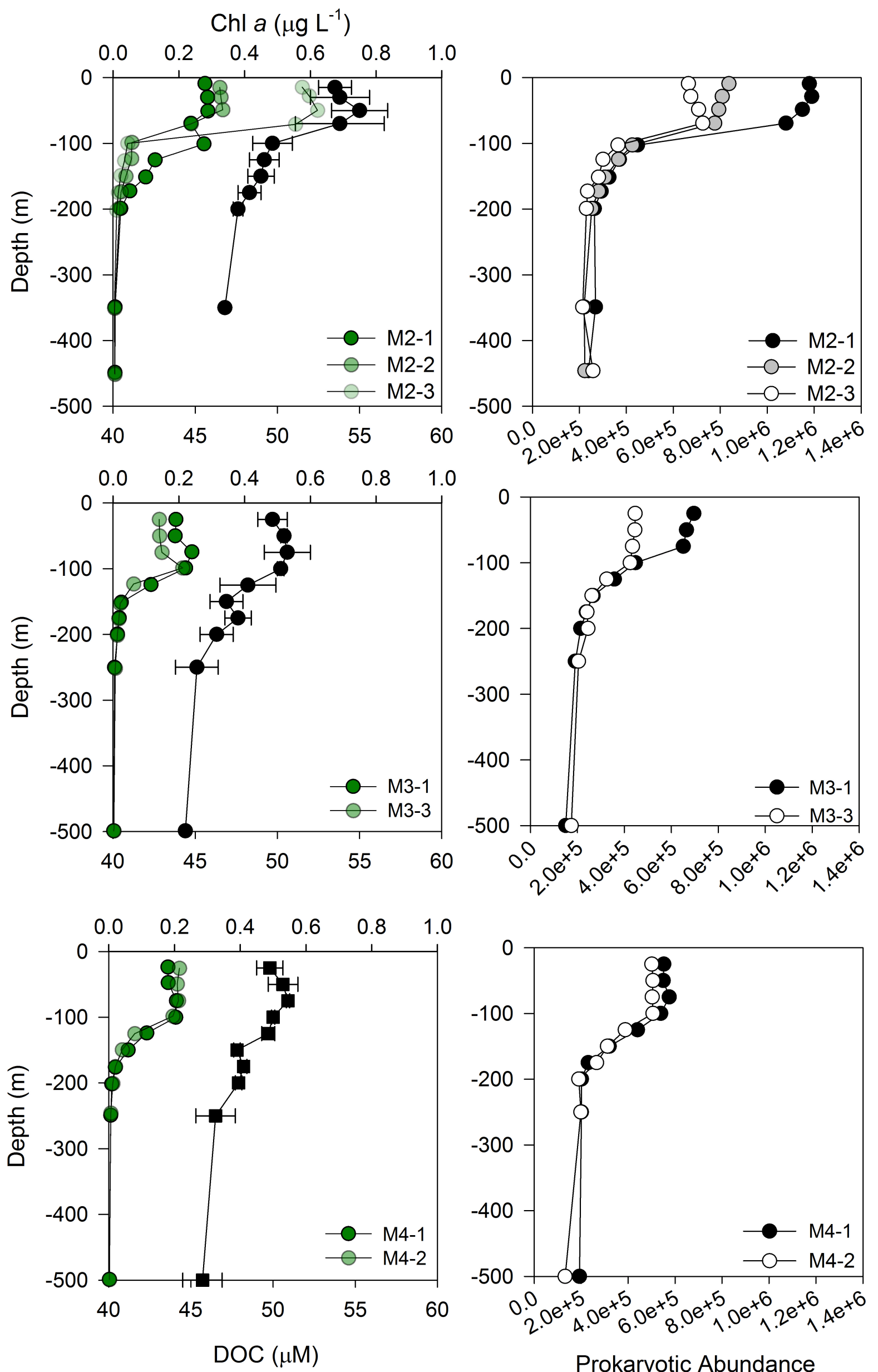

Prokaryotic Abundance (cells $\mathrm{mL}^{-1}$ )

Fig. 2 


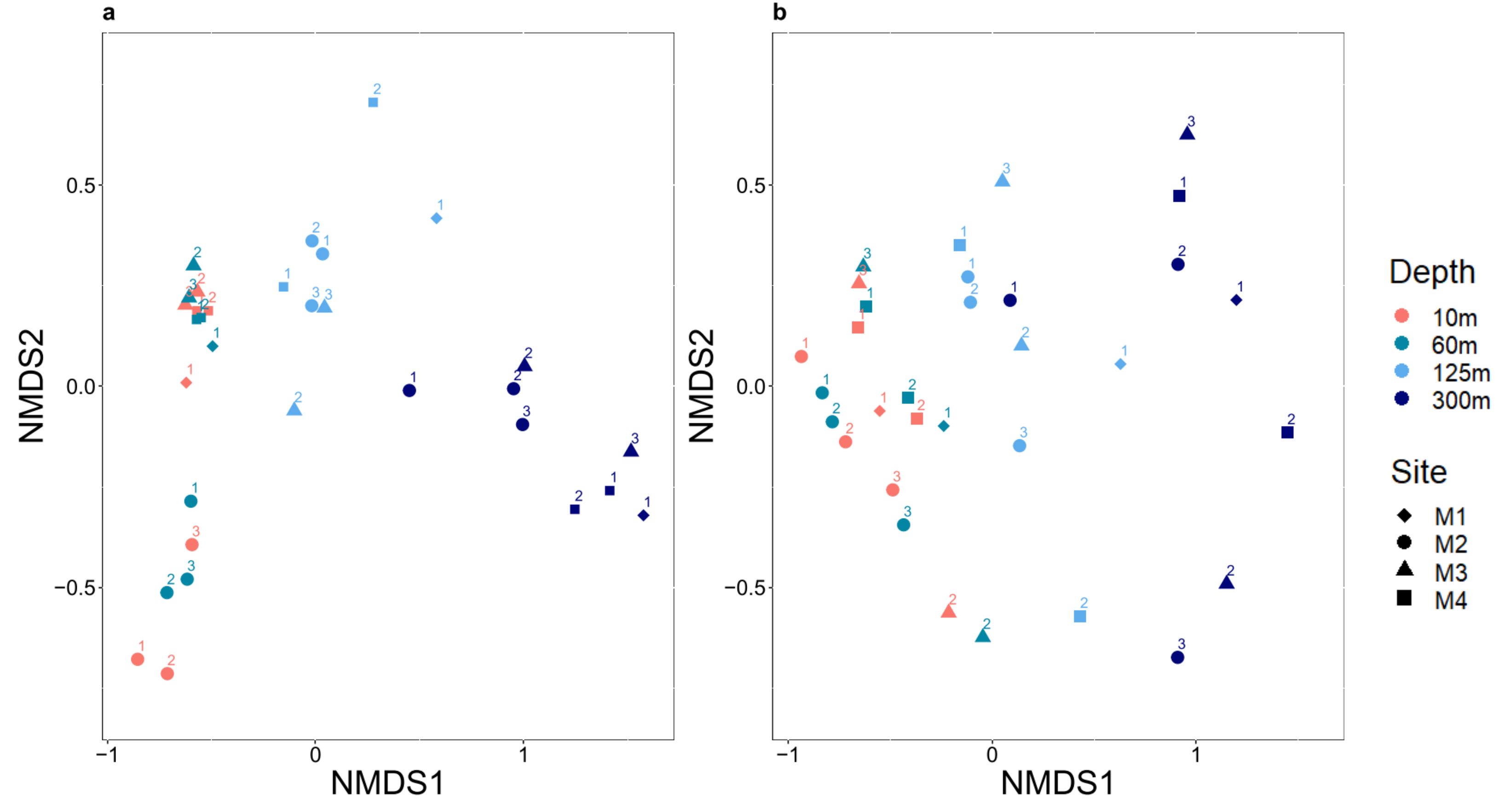

Fig. 3 


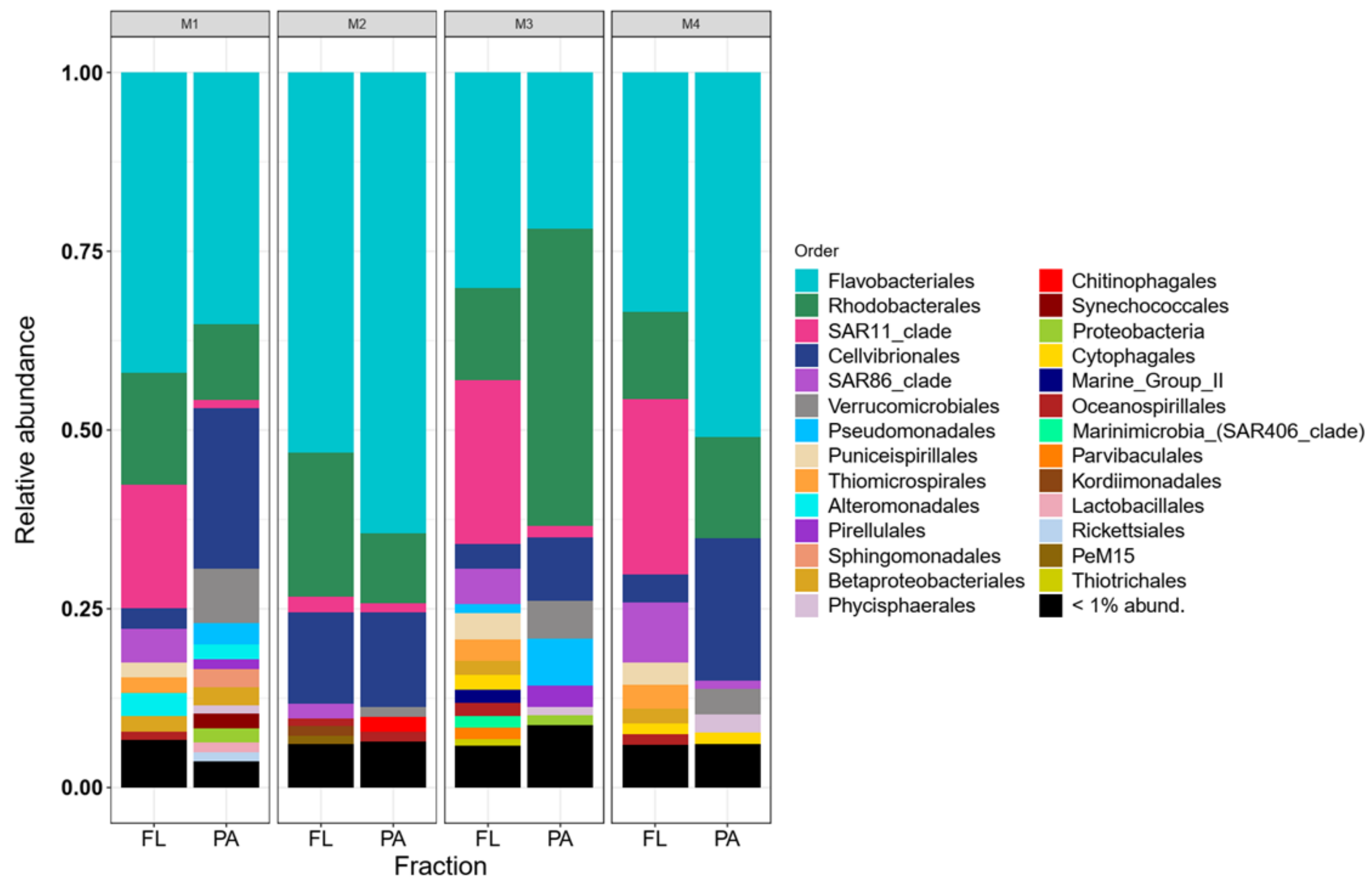

Fig. 4 


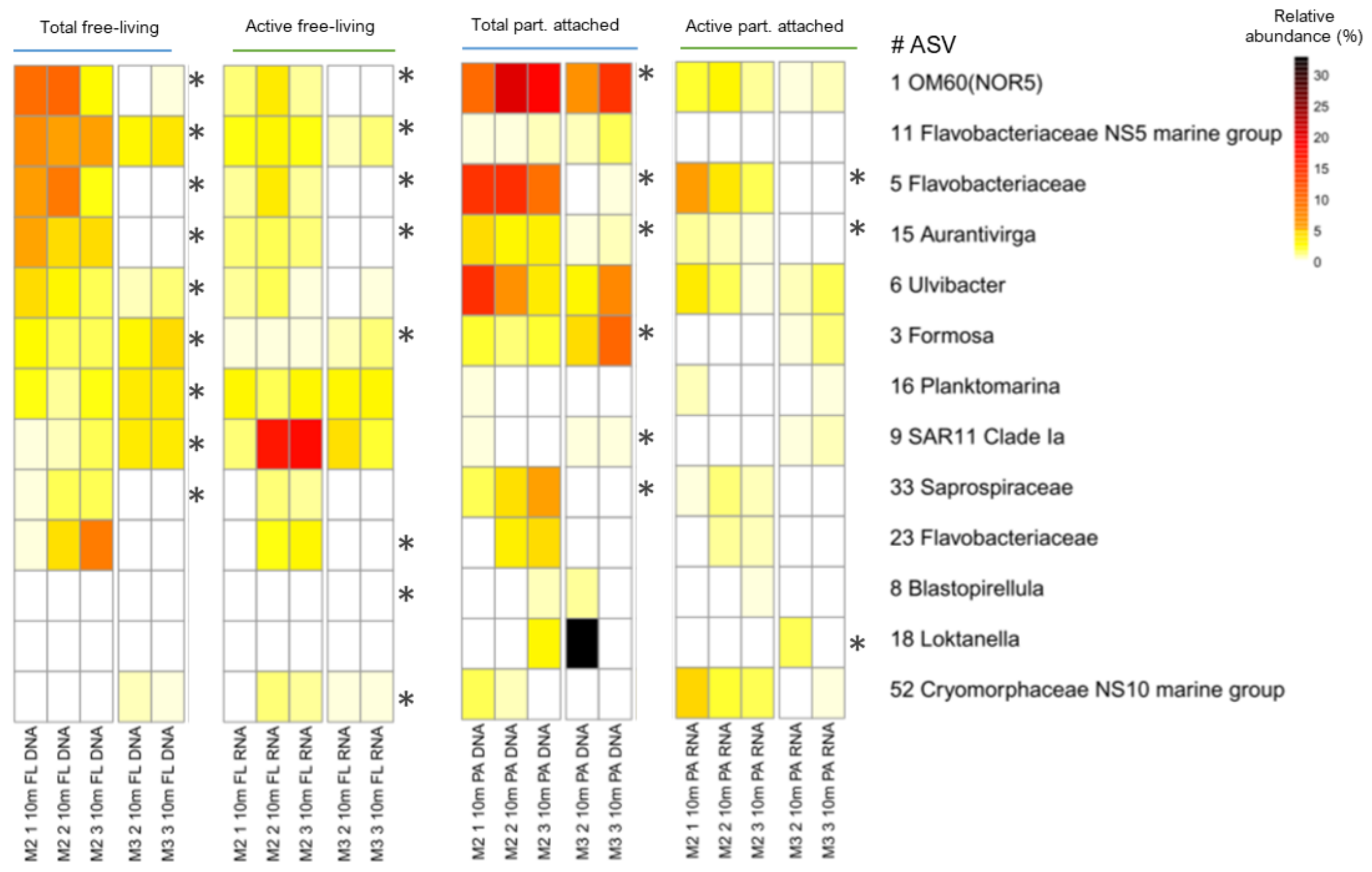

Fig. 5 

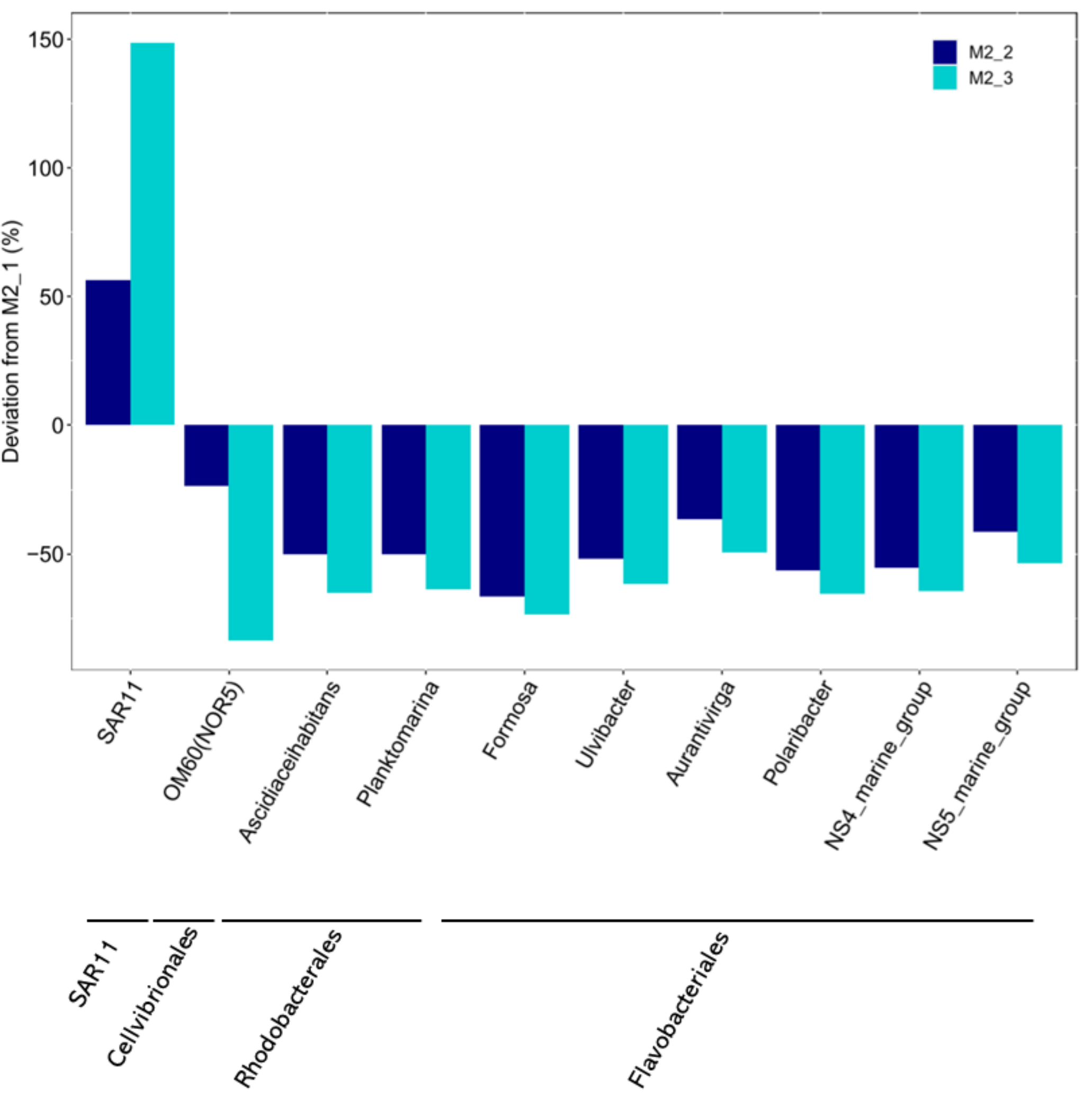

Fig. 6 
Table 1. Brief description of the study sites. The wind-mixed surface layer $\left(Z_{M L}\right)$ is based on a difference in sigma of 0.02 to the surface value. Mean $\pm S D$ of the $Z_{M L}$ are given

\begin{tabular}{|c|c|c|c|c|c|c|c|}
\hline Station & Lat/Long & $\begin{array}{c}\text { Depth } \\
\text { (m) }\end{array}$ & Date & $\begin{array}{c}Z_{M L} \\
(m)\end{array}$ & $\begin{array}{l}\text { Temp } \\
\mathrm{Z}_{\mathrm{ML}} \\
\left({ }^{\circ} \mathrm{C}\right) \\
\end{array}$ & $\begin{array}{c}\text { Chl } a \\
Z_{\mathrm{ML}} \\
\left(\mu \mathrm{g} \mathrm{L}^{-1}\right)\end{array}$ & $\begin{array}{c}\text { DOC } \\
Z_{M L} \\
(\mu \mathrm{M}) \\
\end{array}$ \\
\hline \multicolumn{8}{|c|}{ On plateau } \\
\hline $\begin{array}{l}\text { M2-1 } \\
\text { M2-2 } \\
\text { M2-3 }\end{array}$ & $\begin{array}{l}50.61^{\circ} \mathrm{S} \\
72.00^{\circ} \mathrm{E}\end{array}$ & 527 & $\begin{array}{l}26 \mathrm{Feb} \\
06 \mathrm{Mar} \\
16 \mathrm{Mar}\end{array}$ & $\begin{array}{l}62 \\
61 \\
68\end{array}$ & $\begin{array}{l}5.1 \pm 0.06 \\
5.2 \pm 0.00 \\
5.1 \pm 0.07\end{array}$ & $\begin{array}{l}0.27 \pm 0.02 \\
0.30 \pm 0.04 \\
0.58 \pm 0.02\end{array}$ & $\begin{array}{l}52.8 \pm 0.5 \\
55.7 \pm 1.1 \\
53.8 \pm 1.1\end{array}$ \\
\hline \multicolumn{8}{|c|}{ Off plateau } \\
\hline M1 & $\begin{array}{l}49.84^{\circ} \mathrm{S} \\
74.90^{\circ} \mathrm{E}\end{array}$ & 2723 & 09 March & 27 & $4.9 \pm 0.10$ & $0.35 \pm 0.04$ & $50.3 *$ \\
\hline M3-1 & $50.68^{\circ} \mathrm{S}$ & 1700 & 04 Mar & 65 & $5.6 \pm 0.00$ & $0.20 \pm 0.02$ & $50.3 \pm 0.1$ \\
\hline M3-3 & $68.05^{\circ} \mathrm{E}$ & & $19 \mathrm{Mar}$ & 79 & $5.3 \pm 0.02$ & $0.14 \pm 0.00$ & $50.4 \pm 1.3$ \\
\hline M4-1 & $52.60^{\circ} \mathrm{S}$ & 4300 & $01 \mathrm{Mar}$ & 49 & $4.5 \pm 0.06$ & $0.18 \pm 0.01$ & $49.6 \pm 0.5$ \\
\hline M4-2 & $67.19^{\circ} \mathrm{E}$ & & $12 \mathrm{Mar}$ & 87 & $4.5 \pm 0.00$ & $0.21 \pm 0.00$ & $50.8 \pm 0.4$ \\
\hline
\end{tabular}

*only one data point in the $\mathrm{Z}_{\mathrm{ML}}$ available

Station M3-2 was not sampled for the parameters considered in the present study 
Table 2. Prokaryotic diversity as illustrated by the Shannon Index. Results for the first visit to the off-plateau stations are shown. A full description of the diversity indices is provided in Table S1. NA - Not Available

\begin{tabular}{|c|c|c|c|c|}
\hline \multirow[b]{2}{*}{ Depth (m) } & \multicolumn{2}{|c|}{ Total (DNA) } & \multicolumn{2}{|c|}{ Active (RNA) } \\
\hline & Free-living & Particle-attached & Free-living & Particle-attached \\
\hline \multicolumn{5}{|c|}{ On Plateau } \\
\hline \multicolumn{5}{|l|}{ Station M2-1 } \\
\hline 10 & 4.05 & 3.67 & 6.04 & 5.79 \\
\hline 50 & 4.52 & 3.59 & NA & 5.95 \\
\hline 100 & 4.97 & 3.96 & 6.37 & 6.19 \\
\hline 300 & 5.32 & 4.61 & 5.97 & 6.45 \\
\hline \multicolumn{5}{|l|}{ Station M2-2 } \\
\hline 10 & 4.20 & 3.69 & 4.59 & 5.89 \\
\hline 60 & 4.32 & 3.41 & 6.04 & 4.51 \\
\hline 125 & 4.92 & 4.12 & 5.21 & 5.03 \\
\hline 300 & 5.39 & 5.69 & 5.99 & 6.34 \\
\hline \multicolumn{5}{|l|}{ Station M2-3 } \\
\hline 10 & 4.56 & 3.65 & 4.79 & 6.37 \\
\hline 60 & 4.38 & 3.54 & 4.94 & 5.85 \\
\hline 125 & 5.04 & 3.80 & 6.56 & 6.22 \\
\hline 300 & 5.37 & 3.99 & 6.66 & 4.90 \\
\hline \multicolumn{5}{|c|}{ Off plateau } \\
\hline \multicolumn{5}{|l|}{ Station M1 } \\
\hline 10 & 4.63 & 4.01 & 4.39 & 6.22 \\
\hline 60 & 4.91 & 3.91 & 6.26 & 6.05 \\
\hline 125 & 5.02 & 5.07 & 6.55 & 6.66 \\
\hline 300 & 5.17 & 6.01 & 5.64 & 6.42 \\
\hline \multicolumn{5}{|l|}{ Station M3-1 } \\
\hline 10 & 5.01 & 3.52 & 6.15 & 6.04 \\
\hline 60 & 5.12 & 3.29 & 6.44 & 5.91 \\
\hline 125 & 5.00 & 3.66 & 4.86 & 6.20 \\
\hline 300 & 5.57 & 4.77 & 6.37 & 5.76 \\
\hline \multicolumn{5}{|l|}{ Station M4-1 } \\
\hline 10 & 4.78 & 3.72 & 5.65 & 6.04 \\
\hline 60 & 4.76 & 3.88 & 5.94 & 6.21 \\
\hline 125 & 5.10 & 4.40 & 6.52 & 6.56 \\
\hline 300 & 5.45 & 5.65 & 6.01 & 6.29 \\
\hline
\end{tabular}




\section{Supplementary Material}

for the manuscript

Prokaryotic diversity and activity in contrasting productivity regimes in late summer in the Kerguelen region (Southern Ocean)

Alejandra Elisa Hernandez-Magana ${ }^{1,2} *$, Yan Liu ${ }^{1,3 *}$, Pavla Debeljak ${ }^{1,4 \dagger}$, Olivier Crispi ${ }^{1}$, Barbara Marie $^{1}$, Coco Koedooder ${ }^{1}+$ Ingrid Obernosterer $^{1 \#}$

This file contains

10 Suppl. Figures

4 Suppl. Tables 

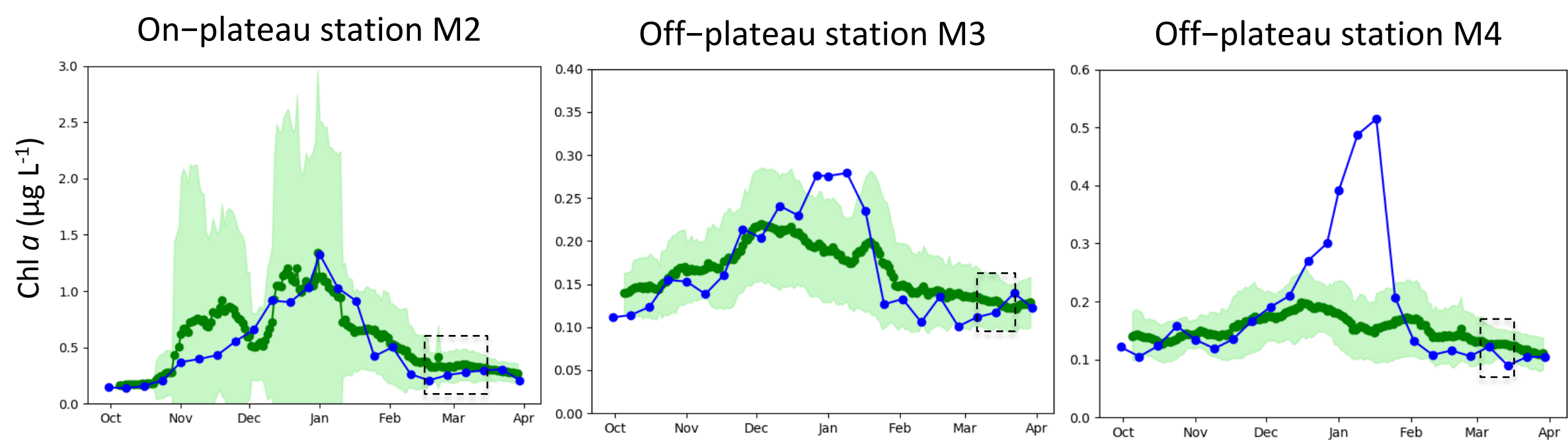

Fig. S1 

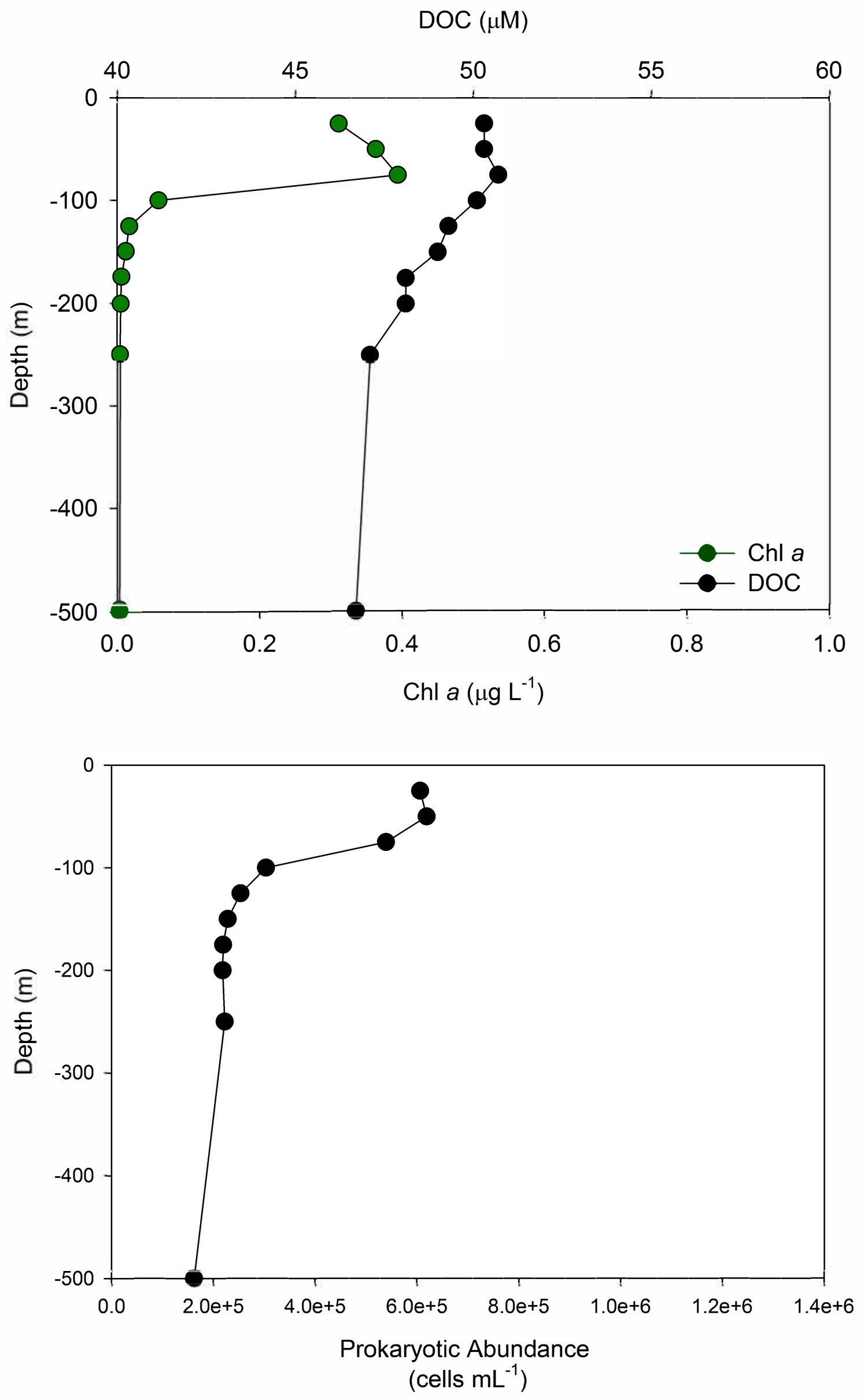

Fig. S3 


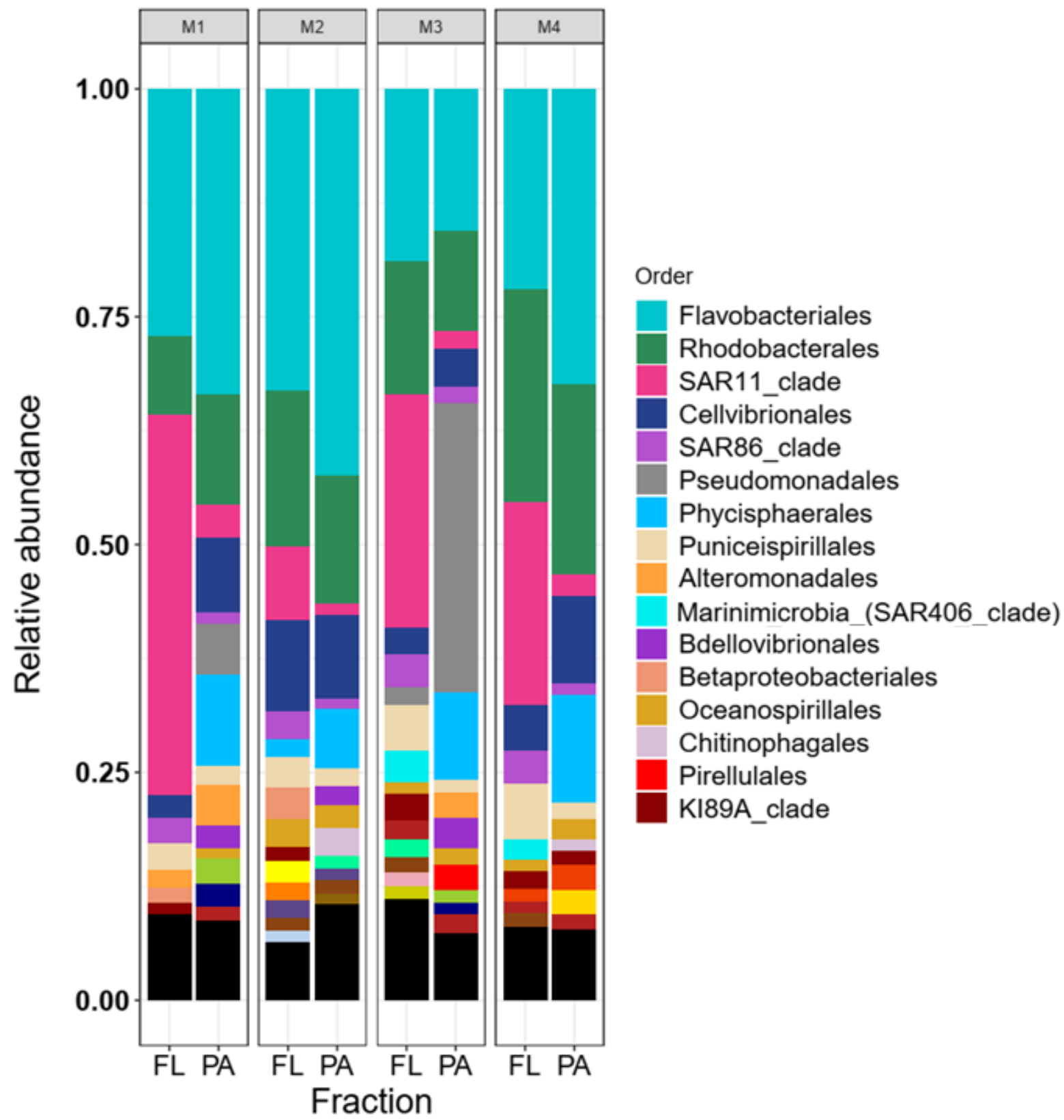

Synechococcales

Cytophagales

Myxococcales

Proteobacteria

PeM15

Gammaproteobacteria

Rhodospirillales

Kordiimonadales

OM182 clade

Thiomicrospirales

Marine_Group_II

Alphaproteobacteria

Thalassobaculales

Unidentified Bacteria

$<1 \%$ abund.

Fig. S5 


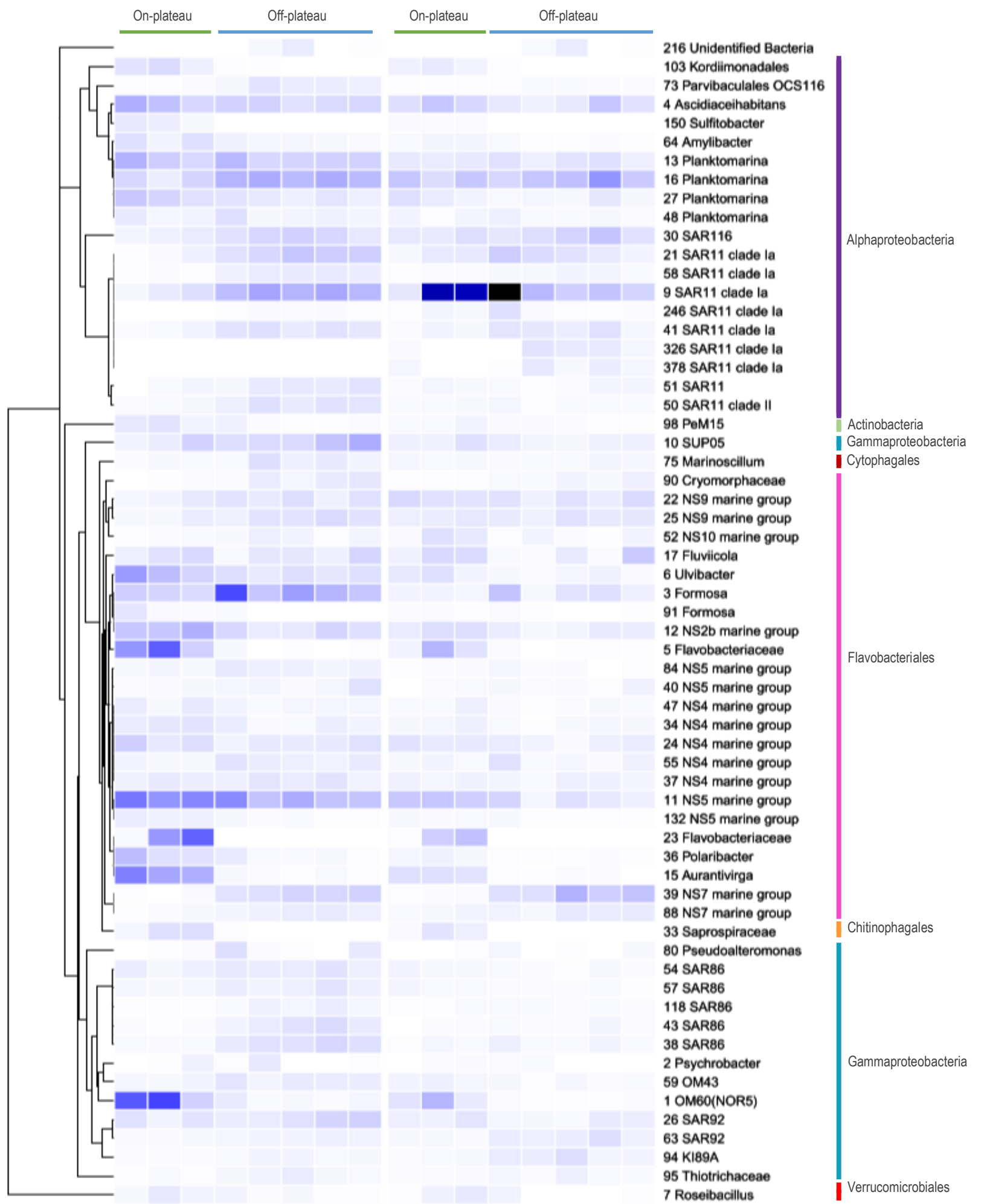

Actinobacteria

Gammaproteobacteria I Cytophagales

Cryomorphacea

22 NS9 marine group 25 NS9 marine group 10 marine group

17 Fluviicola

24 NS4 marine group

55 NS4 marine group

NS4 marine group

54 SAR8 6

57 SAR86

118 SAR86

43 SAR 86

1 OM60(NOR5)

26 SAR92

63 SAR92

95 Thiotrichaceae

7 Roseibacillus

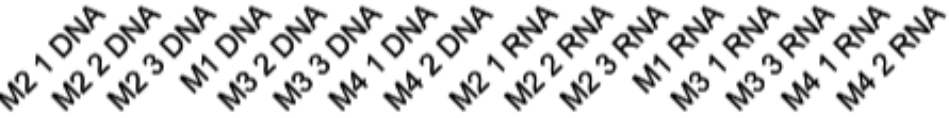

Fig. S6 


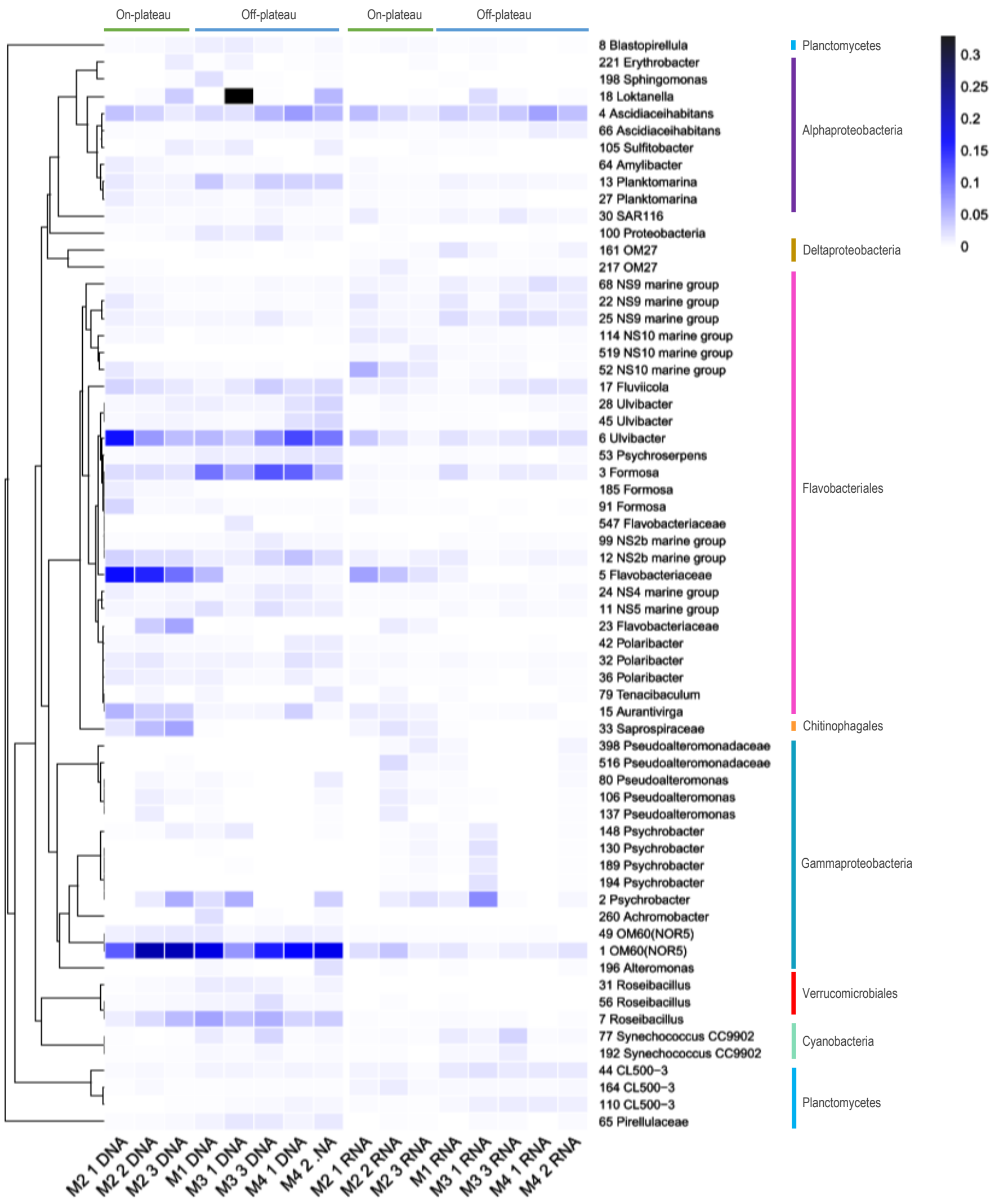

Fig. S7 


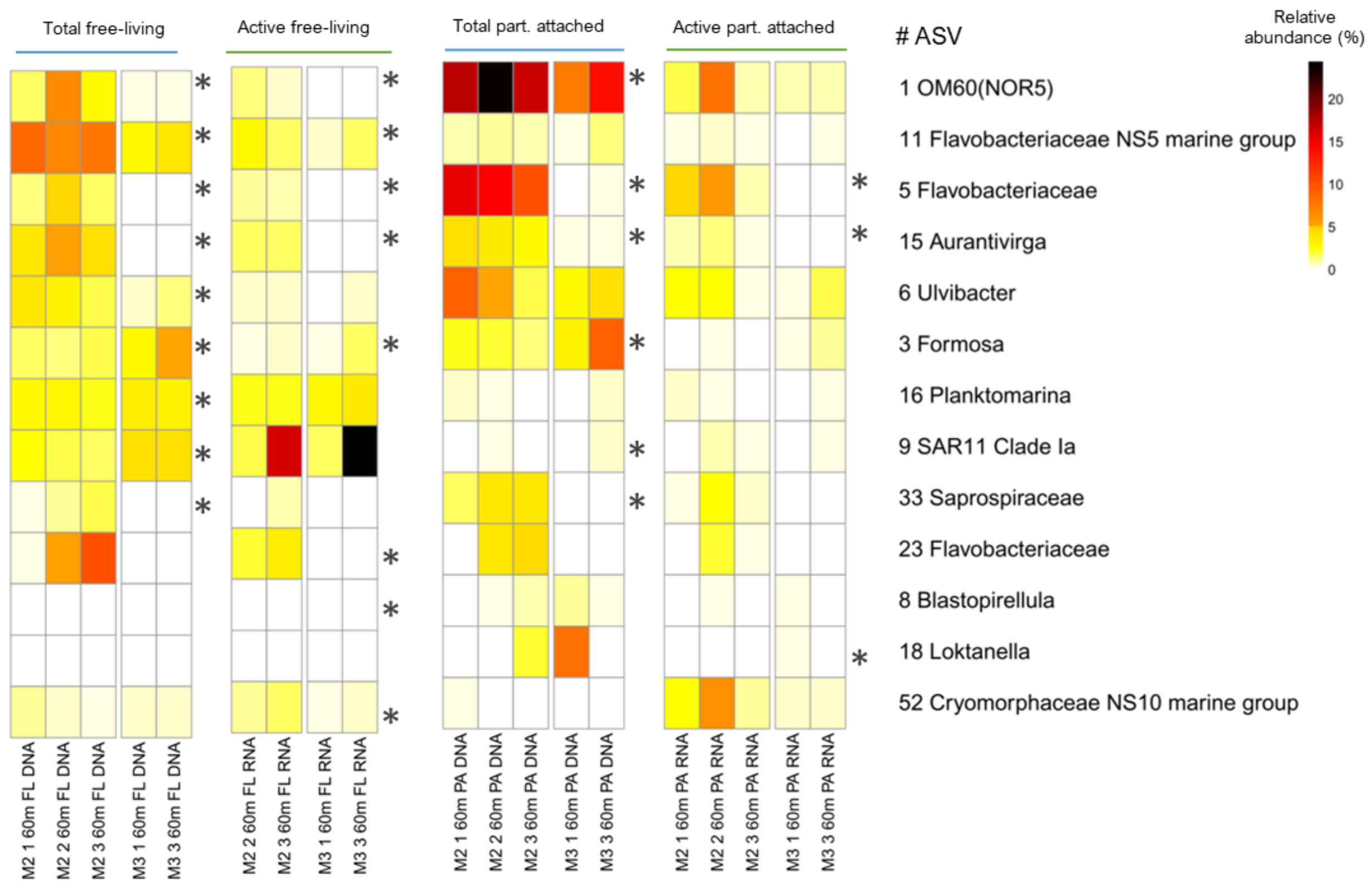

Fig. S8 


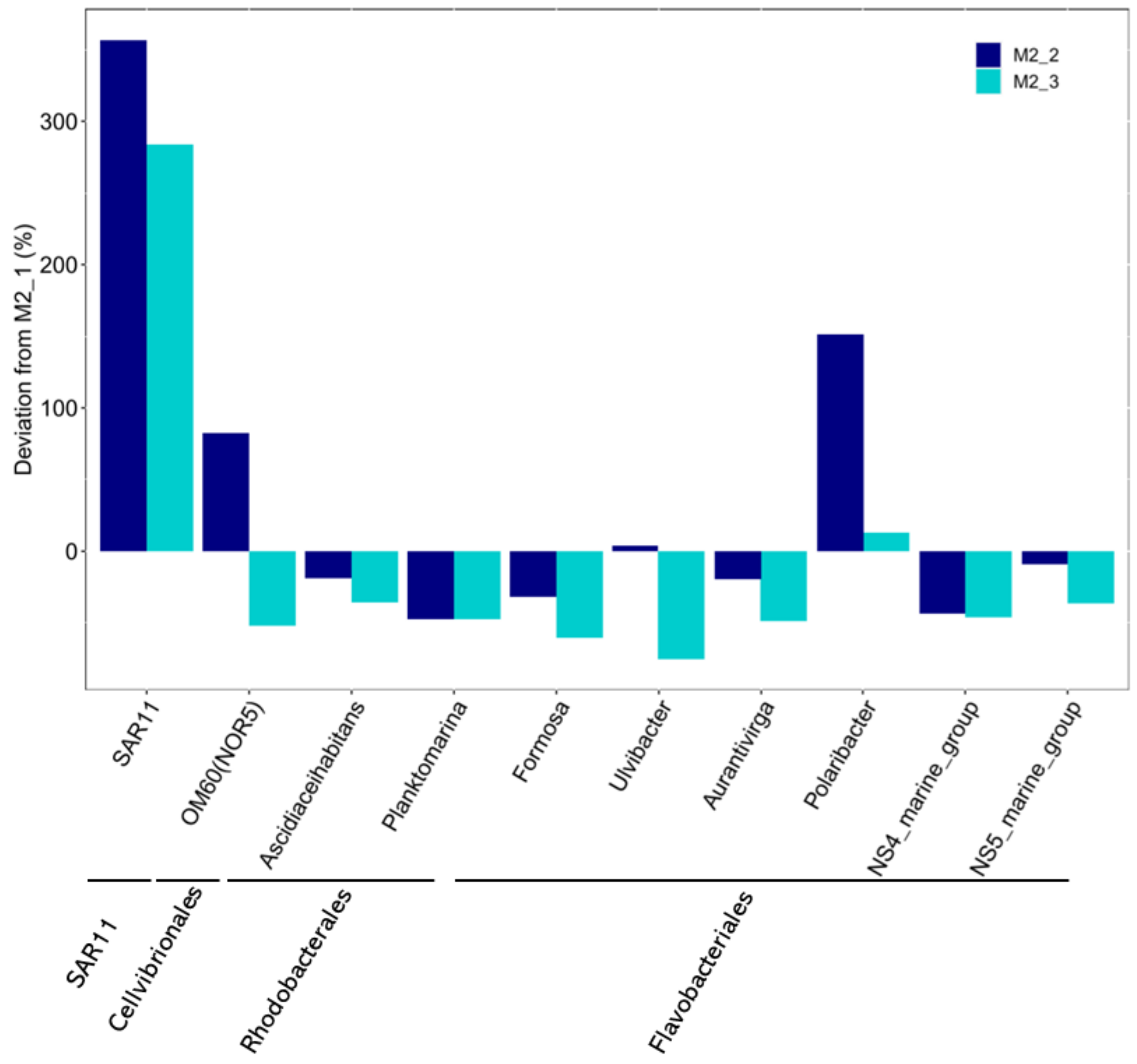

Fig. S9 

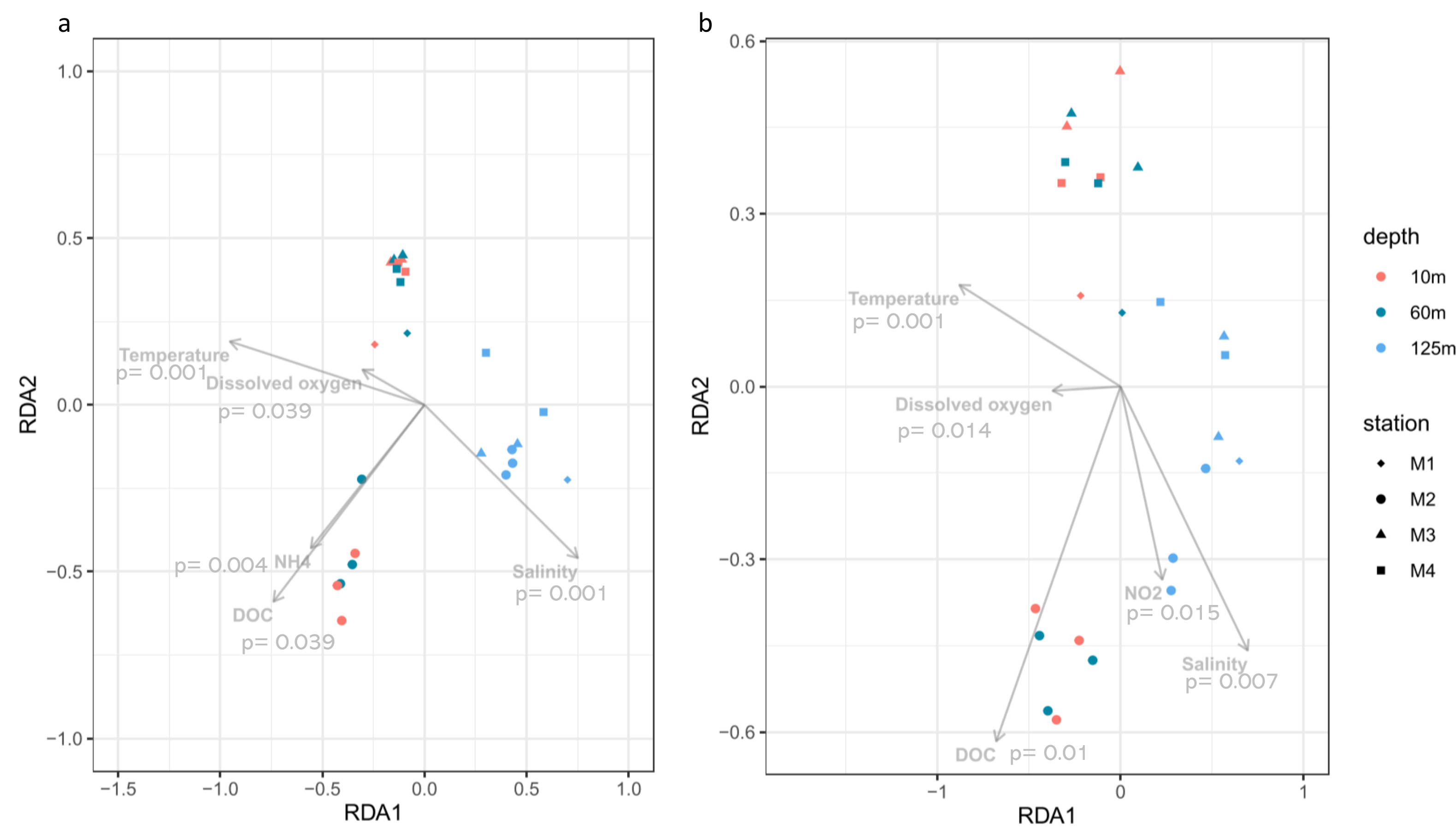

\section{Fig. S10}




\section{Supplementary Figures}

Figure S1. Seasonal bloom dynamics for on-plateau station M2 and off-plateau stations M3 and M4. The green line indicates the 10-year climatological mean (2007-2017) of Chl $a$ concentrations and its SD illustrated as the green shaded area. The blue line denotes Chl $a$ concentrations for the year 2018 (MOBYDICK cruise). Chl $a$ data are from Global Ocean Satellite Observations (Copernicus-GlobColour). Reprocessed data are provided by Copernicus Marine Service. The time period of the MOBYDICK cruise is marked with a rectangle. Note different scales of y-axis.

Figure S2. Depth profiles of temperature and density anomaly for the repeated visits at the 4 stations.

Figure S3. Depth profiles of DOC, prokaryotic abundances and Chl $a$ at station M1.

Figure S4. Non-Metric Multidimensional Scaling (NMDS) of potentially active (RNA) prokaryotic communities in the (a) free-living and (b) particle-attached fraction from all depth layers based on Bray-Curtis Dissimilarity.

Figure S5. Relative abundance of potentially active (RNA) free-living (FL) and particleattached (PA) taxa grouped at order level in surface waters $(10 \mathrm{~m})$. For stations M2, M3 and M4 the mean relative abundances of the repeated visits are shown.

Fig. S6. Relative abundance of ASVs with corresponding phylum (right colored sidebar) in the free-living fraction in surface waters $(10 \mathrm{~m})$. Only ASVs with $>1 \%$ relative abundance in at least one sample are shown. On-plateau in green; off-plateau in blue. DNA: total community, RNA: potentially active community. 
Fig. S7. Relative abundance of ASVs with corresponding phylum (right colored sidebar) in the particle-attached fraction in surface waters $(10 \mathrm{~m})$. Only ASVs with $>1 \%$ relative abundance in at least one sample are shown. On-plateau in green; off-plateau in blue. DNA: total community, RNA: potentially active community.

Fig. S8. Relative abundance of ASVs that contribute significantly $(p<0.05)$ to the dissimilarity between stations M2 and M3 (SIMPER analysis) at 60m. Asterisk highlight significant differences for a given ASV between sites, in either the free-living or particleattached fractions, for the total (DNA) or potentially active (RNA) communities. Only the ASVs with relative abundance $>5 \%$ in at least one of the samples are shown. Note that the ASVs that contribute to the difference among sites are not always the same for the total and the active communities

Fig. S9. Changes in the absolute abundance of dominant taxa (RNA, free-living fraction) between the first and the second (M2_3) and the first and the third (M2_3) visit at station M2 at $10 \mathrm{~m}$. Deviations are given as percent; positive and negative values indicate an increase and a decrease, respectively, in abundance over the repeated visits at station M2. The deviation was calculated based on a formula published in Agogué et al (2011).

Fig. S10. Redundancy analysis of the total community (DNA-based dataset) in the free-living fraction (a) and particle attached (b). The significant environmental response-vectors are shown. Colors indicate water depths and symbol shapes correspond to sites. The variables were selected prior the RDA analysis (with variance inflation $<10$ ) excluding the redundant constraints. 
Table S1. Percent prokaryotic cells in the $0.8 \mu \mathrm{m}$ filtered seawater of cells in unfiltered seawater.

\begin{tabular}{|c|c|c|}
\hline Station & Depth (m) & $\begin{array}{c}\text { Fraction of cells } \\
\text { in }<0.8 \mu \mathrm{m} \text { size } \\
\text { fraction (\%) }\end{array}$ \\
\hline M1 & 15 & 115 \\
\hline M2-1 & 10 & 84 \\
\hline M2-2 & 10 & 93 \\
\hline M2-2 & 60 & 82 \\
\hline M2-3 & 60 & 79 \\
\hline M3-1 & 10 & 91 \\
\hline M3-1 & 60 & 83 \\
\hline M3-3 & 10 & 86 \\
\hline M3-3 & 60 & 83 \\
\hline M4-2 & 15 & 96 \\
\hline
\end{tabular}




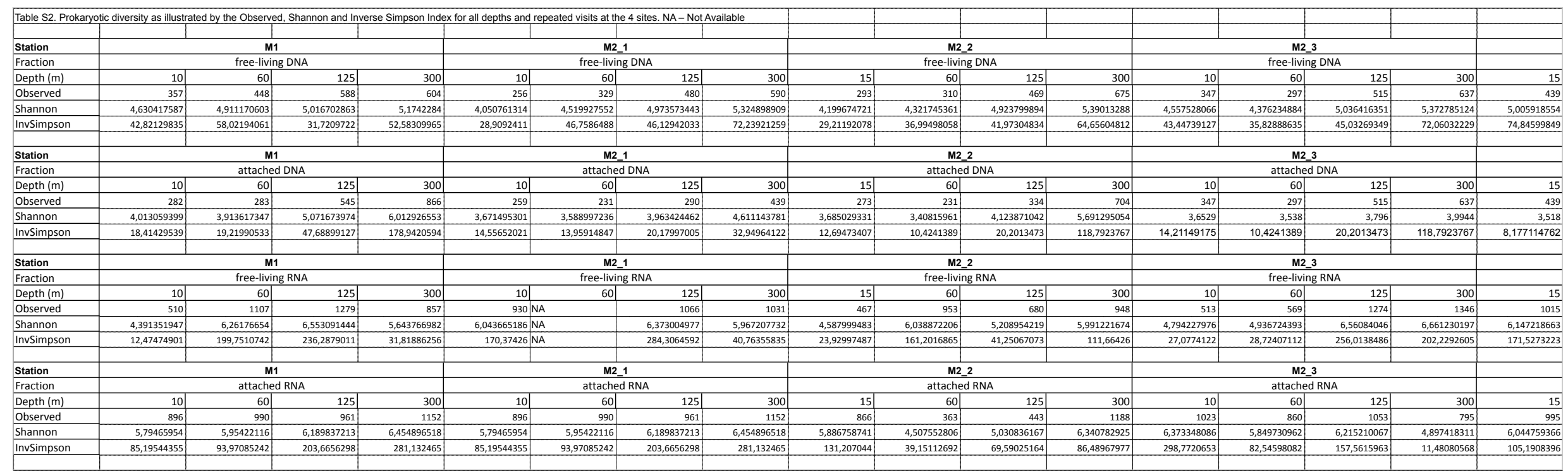




\begin{tabular}{|c|c|c|c|c|c|c|c|c|c|c|c|c|c|c|}
\hline & & & & & & & & & & & & & & \\
\hline & M3_-1 & & \multirow{2}{*}{\multicolumn{4}{|c|}{$\begin{array}{c}\text { M3_2 } \\
\text { free-living DNA }\end{array}$}} & \multirow{2}{*}{\multicolumn{4}{|c|}{$\begin{array}{c}\text { M4_1 } \\
\text { free-living DNA }\end{array}$}} & \multirow{2}{*}{\multicolumn{4}{|c|}{$\begin{array}{c}\text { M4_2 } \\
\text { free-living DNA }\end{array}$}} \\
\hline free-livin & & & & & & & & & & & & & & \\
\hline 60) & 125 & 300 & 15 & 60 & 125 & 300 & 10. & $60 \mid$ & 125 & 300 & 15 & 60 & 125 & 300 \\
\hline $\begin{array}{r}457 \\
5,119911706\end{array}$ & 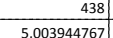 & 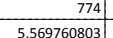 & 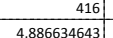 & \begin{tabular}{|c|c|}
3896 & \\
83034
\end{tabular} & $\begin{array}{r}589 \\
8653\end{array}$ & $\begin{array}{r}6595 \\
53363\end{array}$ & 3825 & $\begin{array}{l}388 \\
36847\end{array}$ & 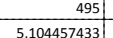 & 6844 & \begin{tabular}{|l|l}
412 & 4399 \\
599 &
\end{tabular} & \begin{tabular}{|c|c|}
4919 \\
9069
\end{tabular} & 618 & $\frac{694}{55036}$ \\
\hline 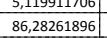 & 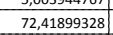 & 79,164196454 & $\mid$ & 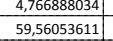 & 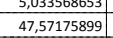 & 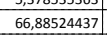 & | 61,40002813 & 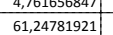 & $\mid$ & $\begin{array}{l}, 44005304550 \\
63,6204237 \\
\end{array}$ & | & $\begin{array}{l}\mid, 489282009069 \\
70,01692317\end{array}$ & 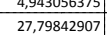 & $\frac{\frac{5,444455036}{65,4002231}}{6}$ \\
\hline & & & & & & & & & & & & & & \\
\hline \multirow{2}{*}{\multicolumn{3}{|c|}{ attached DNA }} & \multicolumn{4}{|c|}{$\begin{array}{c}\text { M3_2 } \\
\text { attach_d DNA }\end{array}$} & \multicolumn{4}{|c|}{$\begin{array}{c}\text { M4_1 } \\
\text { attached DNA }\end{array}$} & \multicolumn{4}{|c|}{$\begin{array}{c}\text { M4_2 } \\
\text { attanthedDA }\end{array}$} \\
\hline & & & \multicolumn{4}{|c|}{$\begin{array}{c}\text { attached DNA } \\
60\end{array}$} & \multicolumn{4}{|c|}{ attached DNA } & \multicolumn{3}{|c|}{ attached DNA } & \\
\hline 457 & 438 & 774 & 288 & $\begin{array}{l}60 \\
298 \\
\end{array}$ & $\mid$\begin{tabular}{|c|}
$\mid 215$ \\
315
\end{tabular} & $\begin{array}{c}300 \\
7711 \\
\end{array}$ & $\frac{104}{243}$ & $\begin{array}{r}600 \\
267 \\
\end{array}$ & $\mid \begin{array}{l}\mid 25 \\
366\end{array}$ & $\frac{300}{669}$ & $\frac{15}{275}$ & $\frac{60}{306}$ & $\frac{1267}{267}$ & $\frac{300}{707}$ \\
\hline 3,286 & 3,6634 & 4,77 & \begin{tabular}{l|l|l|l}
, 997718952 \\
\end{tabular} & \begin{tabular}{ll|l}
4,08066732 \\
\end{tabular} & 3,954872015 & \begin{tabular}{|l}
5,750910961 \\
\end{tabular} & 3,717988494 & \begin{tabular}{|l|l|}
3,884385475 \\
\end{tabular} & 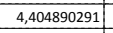 & 5,647105594 & \begin{tabular}{l|l|}
3,969754376 \\
\end{tabular} & $\begin{array}{l}4,070741559 \\
\end{array}$ & 2,928439517 & 5,557859019 \\
\hline 7,240784755 & $\begin{array}{l}13,19206106 \\
\end{array}$ & $\begin{array}{l}16,93033334 \\
\end{array}$ & 20,40416923 & 22,46182369 & 18,90960618 & $\begin{array}{l}129,6652914 \\
\end{array}$ & \begin{tabular}{|l|l|}
16,20826173 \\
\end{tabular} & \begin{tabular}{|l|l|}
19,36629488 \\
\end{tabular} & \begin{tabular}{|l|l|}
29,77360972 \\
\end{tabular} & 125,7471711 & \begin{tabular}{|l|l|}
19,14907738 \\
\end{tabular} & 22,8616917 & $\begin{array}{l}, 5392646999 \\
\end{array}$ & 73,51675384 \\
\hline \multirow{2}{*}{\multicolumn{3}{|c|}{$\begin{array}{c}\text { M3_1 } \\
\text { free-living RNA }\end{array}$}} & \multirow{2}{*}{\multicolumn{4}{|c|}{$\begin{array}{c}\text { M3_2 } \\
\text { free-living RNA }\end{array}$}} & \multirow{2}{*}{\multicolumn{4}{|c|}{$\begin{array}{c}\text { M4_1 } \\
\text { free-living RNA }\end{array}$}} & \multirow{2}{*}{\multicolumn{4}{|c|}{ M4_2 }} \\
\hline & & & & & & & & & & & \multicolumn{2}{|c|}{ free-living RNA } & & \\
\hline 60 & 125 & 300 & \multicolumn{4}{|c|}{$\begin{array}{l}\text { Iree-iving KiNA } \\
60\end{array}$} & \multicolumn{4}{|c|}{ Iree-iving KiNA } & 15 & 60 & 125 & 300 \\
\hline & 680 & & 897 & 523 & 703 & 1033 & 816 & \begin{tabular}{|c|}
945 \\
\end{tabular} & 1213 & 946 & 1027 & 572 & 1351 & 937 \\
\hline 6,443330058 & 4,863603132 & \begin{tabular}{|c|}
6,36983816161 \\
\end{tabular} & \begin{tabular}{|c|}
5,872947044 \\
\end{tabular} & $\mid$ & \begin{tabular}{|l|l|}
5,04721143 \\
\end{tabular} & 6,157978297| & 5,645590785 & |5,936458808 & 6,5245001 & 6,0079269 & \begin{tabular}{|c|}
6,114155036 \\
\end{tabular} & 4,721951749 & 6,647294232 & 6,070729353 \\
\hline \begin{tabular}{|l|l|}
280,3100004 \\
\end{tabular} & 18,29747807 & 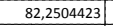 & 127,1842817 & $\mid \begin{array}{l}15,83392416 \\
\end{array}$ & 26,54139064 & 78,5280407 & \begin{tabular}{|c|}
94,82600929 \\
\end{tabular} & $\mid$\begin{tabular}{|c|}
136,7852678 \\
\end{tabular} & 300,0499905 & 102,6859357 & \begin{tabular}{|c|}
161,4269072 \\
\end{tabular} & 18,65007181 & 273,5772002 & 151,9662869 \\
\hline & 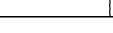 & & \multirow{2}{*}{\multicolumn{4}{|c|}{$\frac{\text { M3_2 }}{\text { attached RNA }}$}} & & & & & & & & \\
\hline \multicolumn{3}{|c|}{$\begin{array}{l}\text { M3_1 } \\
\text { attached RNA }\end{array}$} & & & & & \multicolumn{4}{|c|}{$\begin{array}{l}\text { M4_1 } \\
\text { attached RNA }\end{array}$} & \multicolumn{4}{|c|}{ attached RNA } \\
\hline 60 & 125 & 300 & 15 & 60 & 125 & 300 & 10 & 60 & 125 & 300 & 15 & 60 & 125 & 300 \\
\hline 947 & 9966 & 878 & 1088 & 1089 & 1116 [ & 65 & 943] & 1038 & 270 & 1098 & 1093 & 383 & 9299 & 1243 \\
\hline 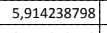 & 6,20376749 & 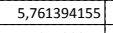 & $\begin{array}{l}6,281651595 \\
6\end{array}$ & $\begin{array}{l}6,284950066 \\
6\end{array}$ & $\begin{array}{l}6,3903076222 \\
\end{array}$ & 6,3650122264 & 6,038599251 & \begin{tabular}{|l|l|}
6,21247134 \\
\end{tabular} & 6,563289489 & 6,293072004 & \begin{tabular}{|c|}
6,2957441049 \\
6
\end{tabular} & \begin{tabular}{|l|l|}
4,636097191 \\
\end{tabular} & \begin{tabular}{|l|l|}
5,7933950001 \\
\end{tabular} & 6,469338878 \\
\hline 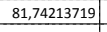 & $\begin{array}{l}41,1394363 \\
\end{array}$ & 75,05190811 & \begin{tabular}{|l|l|}
191,8025779 \\
\end{tabular} & \begin{tabular}{|l|l|}
173,4126956 \\
\end{tabular} & 181,1869336 & 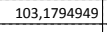 & 130,9402697 & 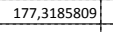 & \begin{tabular}{|l|l|}
247,1549593 \\
\end{tabular} & 95,5618546 & \begin{tabular}{|l|l|}
196,6217623 \\
\end{tabular} & 40,27047017 & \begin{tabular}{|l|l}
67,49777923 \\
\end{tabular} & 159,5258776 \\
\hline & & & & & & & & & & & & & & \\
\hline
\end{tabular}


Table S3. Partial Mantel tests for total (DNA) and potentially active (RNA) prokaryotic community composition, diatom community composition and environmental parameters.

Rho values are shown. ${ }^{* *} \mathrm{p}<0.01, * \mathrm{p}<0.05$. Diatom community composition was determined by microscopic observations and the results are presented in Lafond et al. (2020)

\begin{tabular}{|l|l|l|l|l|}
\hline & \multicolumn{3}{|c|}{ Prokaryotic Community Composition } \\
\hline & \multicolumn{2}{|c|}{ Total } & \multicolumn{2}{c|}{ Active } \\
\hline & \multicolumn{1}{|c|}{ Free-living } & Particle-attached & \multicolumn{1}{|c|}{ Free-living } & Particle-attached \\
\hline $\begin{array}{l}\text { Diatom community } \\
\text { composition }\end{array}$ & $0.6006^{* *}$ & $0.4498^{* *}$ & & $0.5257^{* *}$ \\
\hline $\begin{array}{l}\text { Combined environmental } \\
\text { parameters }\end{array}$ & $0.3525^{* *}$ & $0.3003^{*}$ & $0.3969^{* *}$ & $0.3682^{* *}$ \\
\hline Temperature & $0.2559^{* *}$ & $0.3627^{* *}$ & $0.5493^{* *}$ & $0.3126^{* *}$ \\
\hline Salinity & $0.2553^{*}$ & $0.315^{* *}$ & $0.4528^{* *}$ & $0.3558^{* *}$ \\
\hline Dissolved oxygen & $0.2783^{*}$ & 0.257 & $0.3782^{*}$ & $0.2677^{* *}$ \\
\hline $\mathrm{NH}_{4}^{+}$ & $0.3668^{* *}$ & 0.1354 & 0.1262 & $0.2457^{*}$ \\
\hline $\mathrm{PO}_{4}{ }^{3-}$ & 0.08138 & 0.0796 & 0.114 & 0.1222 \\
\hline $\mathrm{Si}^{-}(\mathrm{OH})_{4}$ & $0.4228^{* *}$ & $0.4413^{* *}$ & $0.6532^{* *}$ & 0.1021 \\
\hline $\mathrm{NO}_{2}^{-}$ & 0.1993 & $0.2615^{*}$ & $0.3636^{*}$ & $0.2568^{*}$ \\
\hline $\mathrm{NO}_{3}{ }^{-}$ & 0.05504 & 0.05192 & 0.07594 & 0.07463 \\
\hline $\mathrm{DOC}$ & $0.3153^{* *}$ & 0.07243 & -0.06333 & 0.1312 \\
\hline
\end{tabular}




\begin{tabular}{|c|c|c|c|c|c|c|c|c|c|c|c|c|c|c|c|c|c|c|c|c|c|c|}
\hline \multicolumn{2}{|c|}{ Hernandez et al. (JMarSyst) } & & & & & & & & & & & & & & & & & & & & & \\
\hline \multicolumn{23}{|c|}{ Table S4. Environmental para } \\
\hline Station & Depth $(\mathrm{m})$ & Salinity & Temp $\left({ }^{\circ} \mathrm{C}\right)$ & Oxygen $(\mu \mathrm{M})$ & $\begin{array}{l}\mathrm{NH}^{2+} \\
(\mathrm{nM})\end{array}$ & $\begin{array}{l}\mathrm{PO4} \\
(\mu \mathrm{M})\end{array}$ & $\begin{array}{c}\mathrm{Si}(\mathrm{OH}) 4 \\
(\mu \mathrm{M})\end{array}$ & $\begin{array}{l}\mathrm{NO} 2 \\
(\mu \mathrm{M})\end{array}$ & $\begin{array}{l}\mathrm{NO} 3 \\
(\mu \mathrm{M})\end{array}$ & $\begin{array}{c}\text { Chlorophyll } \\
\text { c3 (pg/L) }\end{array}$ & $\begin{array}{c}\begin{array}{c}\text { Peridinin } \\
(\mu g / L)\end{array} \\
\end{array}$ & $\begin{array}{c}\text { Fucoxanthin } \\
(\mu g / L)\end{array}$ & $\begin{array}{c}\text { Prasinoxanthin } \\
(\mu \mathrm{pg} / \mathrm{L})\end{array}$ & $\begin{array}{c}19 '- \\
\text { Hexanoyloxyfucox } \\
\text { anthin }(\mu g / L)\end{array}$ & $\begin{array}{c}\text { Alloxanthin } \\
(\mu g / L)\end{array}$ & \begin{tabular}{|} 
Zeaxanthin \\
$(\mu \mathrm{g} / \mathrm{L})$
\end{tabular} & Lutein $(\mu / \mathrm{g} / \mathrm{L})$ & Chlb $(\mu / L)$ & $\begin{array}{c}\text { Chlorophyll_- } \\
\text { a ( } \mu g / L)\end{array}$ & $\begin{array}{l}\mid \begin{array}{l}\text { haeeophyt } \\
\text { in_a ( } \mu g / L)\end{array} \\
\end{array}$ & $\mathrm{POC}(\mu \mathrm{M})$ & $\operatorname{PON}(\mu \mathrm{M})$ \\
\hline M1 & 25 & 33,89 & 5,08 & 322,04 & 421 & 1,63 & 6,49 & 0,28 & 24,76 & 0,0378 & 0,0045 & 0,0738 & 0,0021 & 0,1285 & \begin{tabular}{l|l|}
0,0023 \\
\end{tabular} & 0.0018 & 0,0008 & 0,0096 & 0,3111 & \begin{tabular}{|l|}
0,0019 \\
\end{tabular} & 4,838 & 0,863 \\
\hline M1 & 50 & 33,89 & 4,90 & 320,48 & 712 & 1,67 & 6,9 & 0,29 & 24,55 & 0,0514 & 0,005 & 0,0939 & 0,0035 & 0,1428 & 0,0037 & 0.0016 & 0,0013 & 0,0178 & 0,3633 & 0,0025 & 4,964 & 0,855 \\
\hline M1 & 125 & 34,01 & 1,97 & 296,44 & 0 & 2,15 & 30,02 & 0,03 & 31,47 & 0,0015 & 0,0023 & 0,0116 & 0 & 0,0013 & 0,0004 & 0 & 0 & 0 & 0,0173 & 0,0036 & 1,511 & 0,234 \\
\hline M1 & 250 & 34,22 & 2,21 & 231,95 & 0 & 2,3 & 47,63 & 0,04 & 34,45 & 0,0004 & 0,0012 & 0,0025 & 0 & 0 & 0 & 0 & 0 & 0 & 0,0035 & 0,0022 & 0,907 & 0,174 \\
\hline M2_1 & 9 & 33,86 & 5,17 & 322,09 & 704 & 1,45 & 1,17 & 0,27 & 21,62 & 0,0346 & 0,0103 & 0,077 & 0,0027 & 0,0921 & 0,0031 & 0.0048 & 0,0015 & 0,0109 & 0,2795 & 0,003 & 5,531 & 0,88 \\
\hline M2_1 & 48 & 33,87 & 5,08 & 320,83 & 729 & 1,45 & 1,14 & 0,27 & 21,68 & 0,0416 & 0,0124 & 0,0854 & 0,0022 & 0,1013 & 0,0032 & 0.0046 & 0,002 & 0,0105 & 0,2886 & 0,0031 & 5,481 & 0,837 \\
\hline M2_1 & 124 & 33,93 & 1,88 & 325,59 & 642 & $\begin{array}{l}2,07 \\
\end{array}$ & 22,85 & 0,37 & 28,96 & 0,0038 & 0,0057 & 0,0674 & 0 & 0 & 0 & 0.0006 & 0,0004 & 0 & 0,128 & 0,0149 & 3,447 & 0,382 \\
\hline M2_1 & 349 & 34,25 & 2,08 & 231,70 & 0 & 2,33 & 51,44 & 0,03 & 36,89 & 0,0003 & 0 & 0,0046 & 0 & 0 & 0 & 0 & 0 & 0 & 0,006 & 0,0048 & 3,662 & 0,288 \\
\hline M2_2 & 15 & 33,87 & 5,24 & 316,00 & 1090 & 1,47 & 1,29 & 0,3 & 21,25 & 0,0431 & 0,008 & 0,1124 & 0,0059 & 0,0743 & 0,0037 & 0.004 & 0,001 & 0,0223 & 0,3246 & 0,0025 & 4,437 & 0,691 \\
\hline M2_2 & 50 & 33,86 & 5,24 & 316,15 & 1106 & 1,48 & 1,35 & 0,27 & 21,38 & 0,0429 & 0,0083 & 0,114 & 0,0059 & 0,0751 & 0,0038 & 0.004 & 0,0011 & 0,0227 & 0,3336 & 0,0024 & 3,541 & 0,544 \\
\hline M2_2 & 125 & 33,93 & 2,23 & 319,25 & 297 & 2,05 & 21,69 & 0,32 & 28,95 & 0,0044 & 0 & 0,034 & 0 & 0,0037 & 0 & 0.0004 & 0,0007 & 0 & 0,0561 & 0,0118 & 2,178 & 0,315 \\
\hline M2_2 & 350 & 34,25 & 2,06 & 230,07 & 0 & 2,47 & 51,65 & 0,03 & 34,57 & 0,0003 & 0 & 0,0041 & 0 & 0 & 0 & 0.0002 & 0 & 0 & 0,005 & 0,0054 & 1,161 & 0,153 \\
\hline M2_3 3 & 15 & 33,86 & 5,18 & 318,82 & 899 & 1,51 & 2,6 & 0,3 & 21,75 & 0,0761 & 0,0125 & 0,216 & 0,0184 & 0,1033 & 0,0049 & 0.0047 & 0,0013 & 0,0519 & 0,575 & 0,0045 & 5,915 & 0,933 \\
\hline M2_3 & 50 & 33,86 & 5,07 & 317,59 & 957 & 1,49 & 2,67 & 0,3 & 21,61 & 0,0914 & 0,0173 & 0,2356 & 0,0167 & 0,1239 & 0,0063 & 0.0043 & 0,0015 & 0,0534 & 0,6218 & 0,0061 & 5,984 & 0,966 \\
\hline M2_3 & 127 & 33,95 & 2,11 & 315,71 & 263 & 2,06 & 23,5 & 0,32 & 28,91 & 0,0026 & 0,002 & 0,0212 & 0 & 0,0025 & 0 & 0.0003 & 0,0005 & 0 & 0,0347 & 0,0079 & 1,728 & 0,26 \\
\hline M2_3 & 351 & 34,31 & 2,15 & 214,34 & 0 & 2,34 & 56,46 & 0,04 & 34,56 & 0,0002 & 0 & 0,0033 & 0 & 0 & 0 & 0 & 0 & 0 & 0,0041 & 0,0045 & 1,034 & 0,14 \\
\hline M3_1 & 25 & 33,82 & 5,60 & 314,77 & 501 & $\begin{array}{l}1,62 \\
\end{array}$ & 2,31 & 0,24 & 23,39 & 0,0256 & 0,0049 & 0,034 & 0 & 0,1041 & 0,0013 & 0.0014 & 0 & 0,0073 & 0,191 & 0 & 4,262 & 0,719 \\
\hline M3_1 & 50 & 33,82 & 5,60 & 314,67 & 508 & 1,62 & 2,31 & 0,24 & 23,27 & 0,0256 & 0,0051 & 0,0343 & 0 & 0,1013 & 0,0013 & 0.0014 & 0 & 0,0072 & 0,1892 & 0 & 4,05 & 0,704 \\
\hline M3_1 & 125 & 33,87 & 2,72 & 316,75 & 503 & 1,99 & 18,01 & $\begin{array}{l}0,4 \\
\end{array}$ & 28,04 & \begin{tabular}{|l|l|}
0,0281 \\
\end{tabular} & 0,0056 & 0,0372 & 0 & 0,0502 & 0 & 0.0007 & 0 & 0,0019 & 0,1152 & 0,0062 & 2,288 & 0,347 \\
\hline M3_1 & 250 & 34,06 & 2,23 & 276,04 & 0 & 2,15 & 34,58 & 0,02 & 32,05 & 0,0006 & 0 & 0,0027 & 0 & 0 & 0 & 0 & 0 & 0 & 0,0045 & 0,0018 & 0,998 & 0,187 \\
\hline M3_3 & 24 & 33,81 & 5,32 & 312,90 & 722 & 0,01 & 2,42 & 0,01 & 0,02 & 0,0189 & 0,0045 & 0,029 & 0 & 0,065 & 0,0012 & 0.0006 & 0,0003 & 0,0054 & 0,1402 & 0 & 3,297 & 0,547 \\
\hline M3_3 & 49 & 33,81 & 5,32 & 313,27 & 733 & 1,61 & 2,45 & 0,23 & 23,02 & 0,0193 & 0,0043 & 0,0292 & 0 & 0,0657 & 0,0012 & 0.0006 & 0,0003 & 0,0056 & 0,1413 & 0 & 3,117 & 0,525 \\
\hline M3_3 & 126 & 33,90 & 2,71 & 313,79 & 246 & 2,01 & 20,67 & 0,38 & 28,19 & 0,0119 & 0,0054 & 0,0222 & 0 & 0,0177 & 0 & 0.0004 & 0 & 0,001 & 0,0625 & 0,0052 & 1,644 & 0,254 \\
\hline M3_3 & 249 & 34,03 & 2,21 & 285,48 & 0 & 2,1 & 32,31 & 0,02 & 30,97 & 0,0009 & 0,0004 & 0,0046 & 0 & 0 & 0 & 0.0002 & 0 & 0 & 0,0067 & 0,0024 & 0,993 & 0,127 \\
\hline M4_1 & 23 & 33,85 & 4,50 & 324,05 & 354 & 1,72 & 4,13 & 0,25 & 25,5 & 0,0231 & 0,0039 & 0,0483 & 0 & 0,0832 & 0,0011 & 0.0014 & 0,0004 & 0,003 & 0,1801 & 0 & 3,853 & 0,646 \\
\hline M4_1 & 48 & 33,85 & 4,48 & 323,24 & 349 & 1,68 & 4,19 & 0,25 & 25,5 & 0,0233 & 0,0037 & 0,0547 & 0 & 0,079 & 0,0011 & 0.0016 & 0,0005 & 0,0029 & 0,1811 & 0 & 4,414 & 0,691 \\
\hline M4_1 & 124 & 33,91 & 2,83 & 324,06 & 812 & 1,94 & 18,85 & 0,28 & 27,57 & 0,0221 & 0,0024 & 0,0739 & 0 & 0,0154 & 0 & 0.0009 & 0,0007 & 0,001 & 0,1158 & 0,0064 & 2,932 & 0,43 \\
\hline M4_1 & 251 & 34,07 & 1,73 & 287,82 & 0 & 2,13 & 36,83 & 0,01 & 32,17 & 0,001 & 0 & 0,0043 & 0 & 0,0005 & 0 & 0.0003 & 0 & 0 & 0,006 & 0,0026 & 1,194 & 0,17 \\
\hline M4_2 & 24 & 33,85 & 4,46 & 320,13 & 481 & 1,71 & 4,8 & 0,27 & 24,79 & 0,0278 & 0,003 & 0,0658 & 0 & 0,0857 & 0,0012 & 0.0009 & 0,0006 & 0,0038 & 0,2151 & 0,0013 & 3,745 & 0,564 \\
\hline M4_2 & 52 & 33,85 & 4,46 & 320,23 & 495 & 1,71 & 4,8 & 0,27 & 24,27 & 0,0275 & 0,0033 & 0,0641 & 0 & 0,0847 & 0,0012 & 0.0009 & 0,0007 & 0,0037 & 0,2078 & 0 & 3,536 & 0,58 \\
\hline M4_2 & 125 & 33,91 & 2,56 & 320,07 & 930 & 1,99 & 20,54 & 0,35 & 26,91 & 0,0141 & 0,0015 & 0,0408 & 0 & 0,0186 & 0 & 0.0005 & 0,0003 & 0,0047 & 0,0785 & 0,0035 & 2,074 & 0,329 \\
\hline M4_2 & 246 & 34,07 & 1,96 & 282,39 & 0 & 2,13 & 34,66 & 0,04 & 30,94 & 0,0006 & 0,0012 & 0,0033 & 0 & 0 & 0 & 0 & 0 & 0 & 0,0056 & 0,0021 & 1,136 & 0,153 \\
\hline
\end{tabular}




\begin{tabular}{|c|c|c|c|c|c|}
\hline $\operatorname{DOC}(\mu \mathrm{M})$ & $\begin{array}{l}\text { Prokaryotic } \\
\text { Abundance } \\
\text { (cells } / m L \text { ) }\end{array}$ & $\begin{array}{l}\text { Photosynthetic Pico- } \\
\text { Nanoeukaryotes } \\
\text { (cells/mL) }\end{array}$ & $\begin{array}{l}\text { Heterotrophic } \\
\text { Nanoflagellates } \\
\text { (cells } / \mathrm{mL})^{*}\end{array}$ & $\begin{array}{c}\text { Viral like } \\
\text { particles } \\
(\text { VLPs } / \mathrm{mL})^{*}\end{array}$ & $\begin{array}{l}\text { Bacterial } \\
\text { Production } \\
(\mu g \mathrm{ClLh} /)^{*}\end{array}$ \\
\hline 50,3 & 606000 & 8040 & 943 & $3,10 \mathrm{E}+06$ & 21,54 \\
\hline 50,3 & 619000 & 8010 & 964 & $3,69 \mathrm{E}+06$ & 18,04 \\
\hline 48,1 & 253000 & 38,5 & 366 & $2,05 E+06$ & 1,97 \\
\hline 46,2 & 222000 & 25,2 & 168 & $1,28 \mathrm{E}+06$ & 1 \\
\hline 52,5 & 1180000 & 3190 & 1340 & 4810000 & 22,16 \\
\hline 53,4 & 1150000 & 2770 & 1700 & 5850000 & 30,99 \\
\hline 49,8 & 371000 & 41,5 & 466 & 2110000 & 5,01 \\
\hline 46,8 & 269000 & 16,3 & 257 & 1170000 & 1,37 \\
\hline 54,6 & 837000 & 3770 & 2840 & $8,02 E+06$ & 46,23 \\
\hline 56,7 & 794000 & 3490 & 2910 & $7,11 \mathrm{E}+06$ & 35,81 \\
\hline 49 & 367000 & 80 & 726 & $2,94 \mathrm{E}+06$ & 4,59 \\
\hline 46,8 & 220000 & 13,3 & 278 & $1,31 \mathrm{E}+06$ & 1,3 \\
\hline 54,6 & 665000 & 8130 & 1730 & $7,40 E+06$ & 56,91 \\
\hline 55 & 708000 & 8410 & 1890 & $7,27 \mathrm{E}+06$ & 45,09 \\
\hline 49 & 301000 & 56,1 & 551 & $2,43 E+06$ & 3,58 \\
\hline 45,9 & 214000 & 14,8 & 300 & $1,09 \mathrm{E}+06$ & 1,27 \\
\hline 50,4 & 696000 & 3720 & 625 & $3,64 \mathrm{E}+06$ & 15,59 \\
\hline 50,2 & 665000 & 3590 & 763 & $3,65 \mathrm{E}+06$ & 14,39 \\
\hline 47 & 358000 & 42,8 & 655 & $2,40 \mathrm{E}+06$ & 4,5 \\
\hline 44,2 & 191000 & 7,38 & 222 & $1,52 E+06$ & 0,41 \\
\hline 49,1 & 446000 & 1490 & 847 & $4,10 \mathrm{E}+06$ & 13,18 \\
\hline 52 & 445000 & 1520 & 798 & $3,71 \mathrm{E}+06$ & 13,76 \\
\hline 49,4 & 325000 & 33,9 & 931 & $2,83 E+06$ & 3,62 \\
\hline 44,2 & 205000 & 10,3 & 362 & $2,25 \mathrm{E}+06$ & 1,69 \\
\hline 49,3 & 552000 & 3180 & 851 & $3,45 \mathrm{E}+06$ & 13,98 \\
\hline 50 & 550000 & 3160 & 965 & $3,80 \mathrm{E}+06$ & 13,1 \\
\hline 49,4 & 440000 & 220 & 655 & $3,00 \mathrm{E}+06$ & 6,82 \\
\hline 44,9 & 193000 & 8,4 & 178 & $1,43 E+06$ & 0,3 \\
\hline 49,5 & 501000 & 3700 & 884 & 3320000 & 14,39 \\
\hline 51,2 & 506000 & 3760 & 889 & 3060000 & 14,81 \\
\hline 50 & 388000 & 104 & 658 & 2740000 & 5,56 \\
\hline 44,9 & 199000 & 4,2 & 301 & 1390000 & 0,51 \\
\hline
\end{tabular}

